Utah State University

DigitalCommons@USU

\title{
Hydrologic and Erosion Responses to Wildfire Along the Rangeland-Xeric Forest Continuum in the Western US: A Review and Model of Hydrologic Vulnerability
}

Christopher Jason Williams

USDA, Agricultural Research Service

Frederick B. Pierson

USDA, Agricultural Research Service

Peter R. Robichaud

USDA Forest Service

Jan Boll

University of Idaho

Follow this and additional works at: https://digitalcommons.usu.edu/sagestep_articles

Part of the Plant Sciences Commons

\section{Recommended Citation}

Williams, C. J., F. B. Pierson, P. R. Robichaud, and J. Boll. 2014. Hydrologic and erosion responses to wildfire along the rangeland-xeric forest continuum in the western US: A review and model of hydrologic vulnerability. International Journal of Wildland Fire 23:155-172.

This Article is brought to you for free and open access by the Publications at DigitalCommons@USU. It has been accepted for inclusion in Articles by an authorized administrator of DigitalCommons@USU. For more information, please contact digitalcommons@usu.edu.

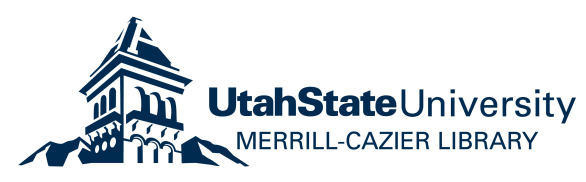




\title{
Hydrologic and erosion responses to wildfire along the rangeland-xeric forest continuum in the western US: a review and model of hydrologic vulnerability
}

\author{
C. Jason Williams ${ }^{\mathrm{A}, \mathrm{B}, \mathrm{E}}$, Frederick B. Pierson ${ }^{\mathrm{A}}$, \\ Peter R. Robichaud ${ }^{\mathrm{C}}$ and Jan Boll ${ }^{\mathrm{B}, \mathrm{D}}$ \\ ${ }^{A}$ Northwest Watershed Research Center, Agricultural Research Service, US Department \\ of Agriculture, 800 Park Boulevard, Plaza 4, Suite 105, Boise, ID 83712, USA. \\ ${ }^{B}$ Environmental Science and Water Resources, University of Idaho, Moscow, ID 83844, USA.

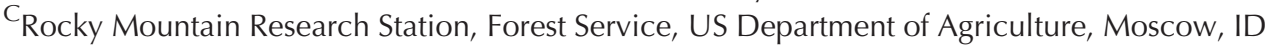 \\ 83843, USA. \\ ${ }^{D}$ Department of Biological and Agricultural Engineering, University of Idaho, \\ Moscow, ID 83844, USA. \\ ${ }^{\mathrm{E}}$ Corresponding author. Email: jason.williams@ars.usda.gov
}

\begin{abstract}
The recent increase in wildfire activity across the rangeland-xeric forest continuum in the western United States has landscape-scale consequences in terms of runoff and erosion. Concomitant cheatgrass (Bromus tectorum L.) invasions, plant community transitions and a warming climate in recent decades along grassland-shrubland-woodlandxeric forest transitions have promoted frequent and large wildfires, and continuance of the trend appears likely if warming climate conditions prevail. These changes potentially increase overall hydrologic vulnerability by spatially and temporally increasing soil exposure to runoff and erosion processes. Plot and hillslope-scale studies demonstrate burning may increase event runoff or erosion by factors of 2-40 over small-plot scales and more than 100-fold over large-plot to hillslope scales. Reports of flooding and debris flow events from rangelands and xeric forests following burning show the potential risk to natural resources, property, infrastructure and human life. We present a conceptual model for evaluating post-fire hydrologic vulnerability and risk. We suggest that post-fire risk assessment of potential hydrologic hazards should adopt a probability-based approach that considers varying site susceptibility in conjunction with a range of potential storms and that determines the hydrologic response magnitudes likely to affect values-at-risk. Our review suggests that improved risk assessment requires better understanding in several key areas including quantification of interactions between varying storm intensities and measures of site susceptibility, the varying effects of soil water repellency, and the spatial scaling of post-fire hydrologic response across rangeland-xeric forest plant communities.
\end{abstract}

Additional keywords: cheatgrass, climate change, fire effects, grass-fire cycle, Great Basin, hydrologic risk, invasive plants, juniper, pinyon, runoff, sagebrush, wildland-urban interface, woodland encroachment.

Received 29 September 2012, accepted 22 August 2013, published online 6 February 2014

\section{Introduction}

Wildfire activity is increasing along the rangeland-xeric forest continuum of the interior western United States (US; Littell et al. 2009; Miller et al. 2009; Litschert et al. 2012; Balch et al. 2013). A vast expanse of the western US is dominated by an arid to semi-arid climate with less than 100 -cm annual precipitation (Fig. 1a) and vegetation that transitions from rangelands to pinyon-juniper woodlands (Pinus spp., Juniperus spp.) or xeric ponderosa pine (Pinus ponderosa Lawson \& C. Lawson) forests across low- to mid-elevations (Fig. 1b). Over the past decade, more than $1 \times 10^{6}$ ha of the western US were burnt by wildfire annually, and much of this was along the rangeland-xeric forest continuum (NIFC 2012). Periods of recurring high wildfire activity in the western US are not unprecedented in the paleo-record (Pierce et al. 2004; Heyerdahl et al. 2008a, 2008b; Whitlock et al. 2008, 2011; Marlon et al. 2012) but the frequency of large fires $(>400 \mathrm{ha})$ and annual area burnt have increased in recent decades (Westerling et al. 2006; Keane et al. 2008; Morgan et al. 2008; Littell et al. 2009; Miller et al. 2011a).

Cheatgrass (Bromus tectorum L.) invasion is the primary cause of increased fire frequency and annual area burnt on sagebrush rangelands throughout the western US (Keane et al. 2008; Miller et al. 2011a; Balch et al. 2013). The species is now a major plant constituent on $4 \times 10^{6}-7 \times 10^{6}$ ha of sagebrush rangelands in the Great Basin alone (Fig. 1b; Knapp 1996; Bradley and Mustard 2005; Miller et al. 2011a). Cheatgrass infill of areas between woody plants affects wildfire activity by increasing the horizontal continuity of fuels and the likelihood 
(a)

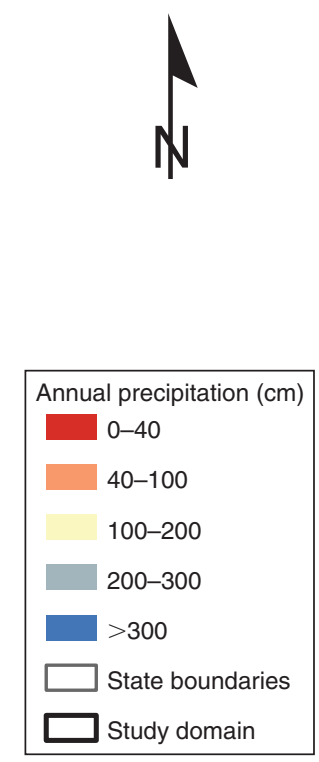

(b)

\begin{tabular}{|l|}
\hline Landcover \\
Water-wetland \\
Forest \\
Rangeland \\
Pasture-cropland \\
Other \\
State boundaries \\
Sreat Basin Desert \\
\hline Study domain
\end{tabular}

0 $250 \quad 500$
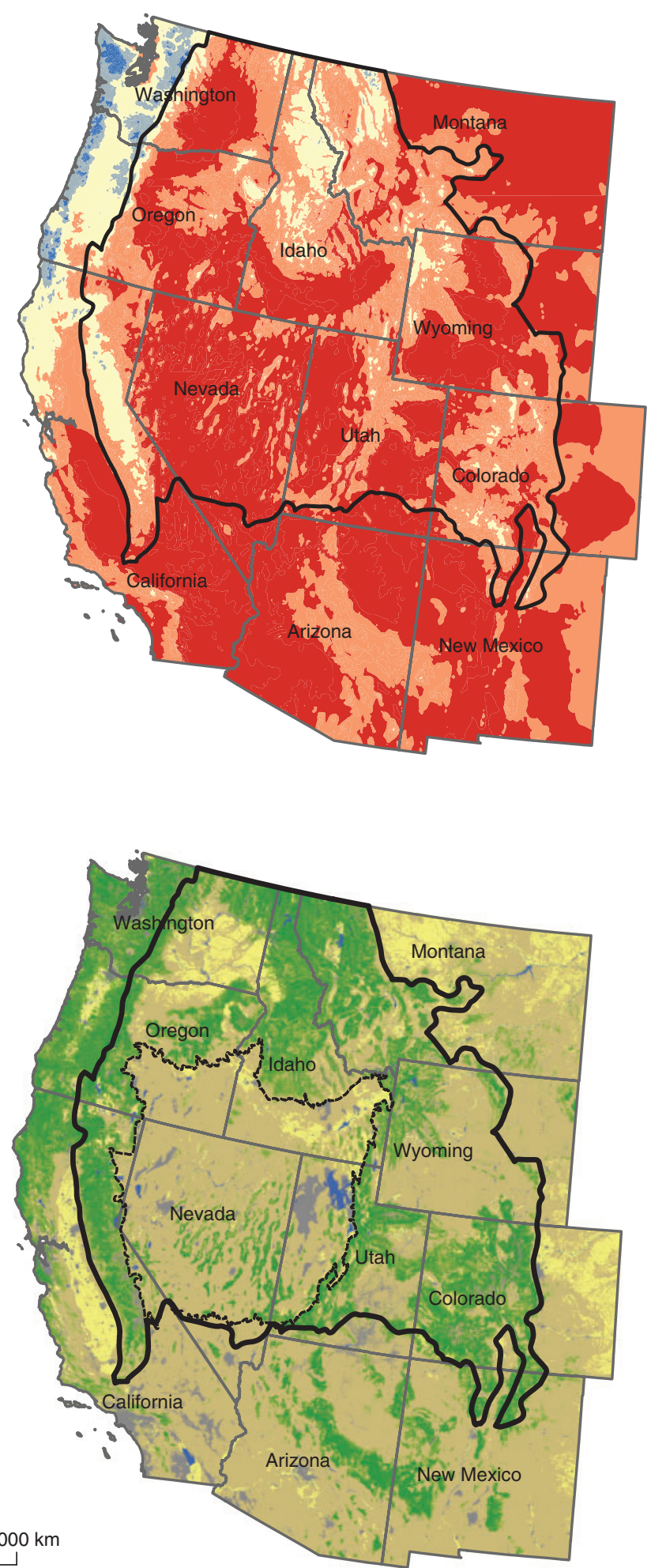

Fig. 1. Map of annual precipitation (a) (Prism Climate Group 2012) and landcover (b) (USGS 2012) across the western United States. The approximate geographic area of the study domain is delineated by the bold black line in each map. The boundary of the Great Basin Desert (rangeland and woodland region with high wildfire activity) is delineated with a dashed black line on the landcover map. 


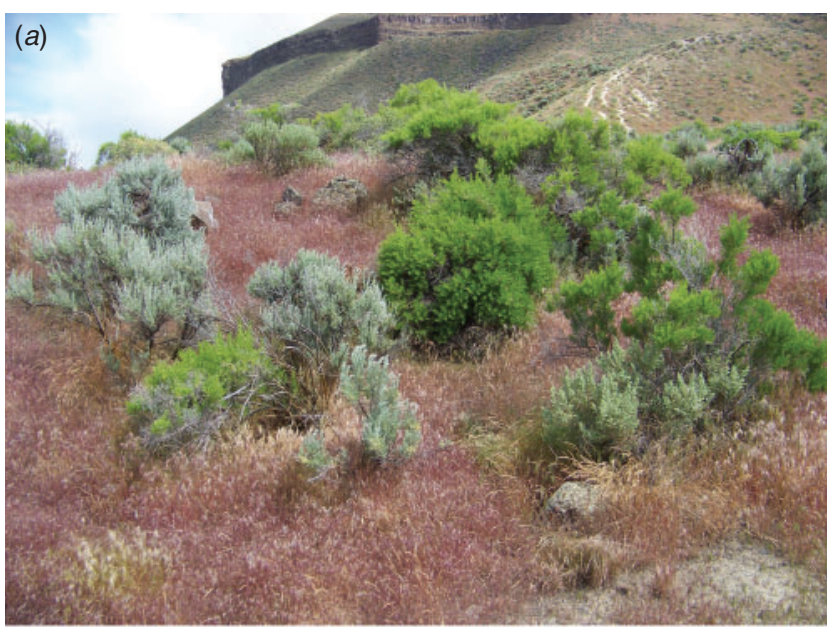

(b)

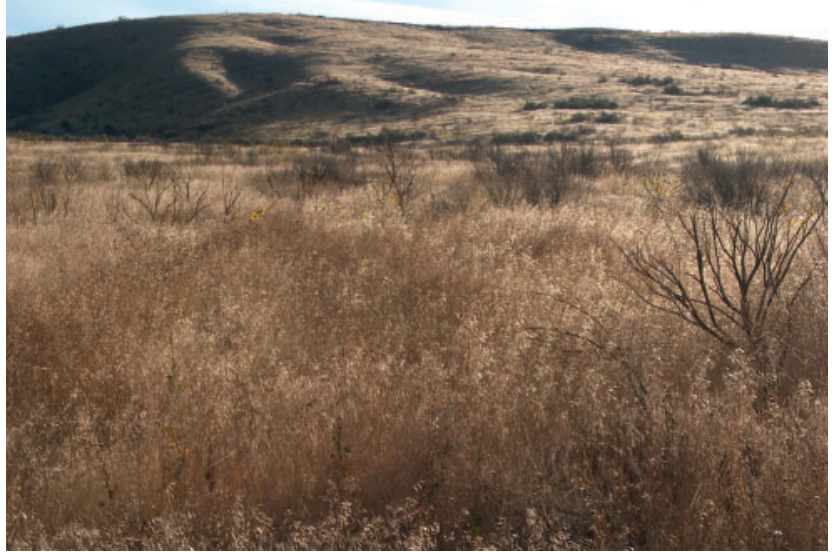

Fig. 2. Sagebrush rangeland with cheatgrass-infested interspace between shrubs $(a)$ and a burnt sagebrush site with nearly $100 \%$ cover of cheatgrass 1 year post-fire $(b)$

of ignition (Fig. 2a; Brooks et al. 2004; Link et al. 2006; Davies et al. 2012). Fire return intervals in cheatgrass-infested rangelands are commonly 10-fold shorter than those for intact sagebrush-bunchgrass communities (Miller et al. 2011a). Frequent re-burning of cheatgrass-invaded rangelands promotes a grass-fire cycle that in turn perpetuates cheatgrass dominance (Knapp 1996; Brooks et al. 2004; Davies et al. 2012; Balch et al. 2013). Cheatgrass produces more seeds post-fire than do native species (Humphrey and Schupp 2001) and commonly outcompetes native bunchgrasses for soil nutrients and water (Harris 1967; Mack and Pyke 1983; Aguirre and Johnson 1991; Duke and Caldwell 2001). The higher seedling vigour and reproduction potential of cheatgrass relative to other species promote a decline in site species richness and evenness with increasing cheatgrass coverage (Mack 1981; Melgoza and Nowak 1991). Repeated fires over short rotations kill newly established shrubs and perennial grasses, exhaust native seed sources and propagate highly flammable cheatgrass monocultures (Fig. 2b; Welch 2005; Davies et al. 2012).

Woodland expansion and infill on rangelands have made much of the western US prone to large severe wildfires
(Keane et al. 2008; Romme et al. 2009). Native pinyon and juniper species have dramatically increased their range in the past 150 years and currently occupy more than $3.0 \times 10^{7}$ ha of the western US (Miller and Tausch 2001; Davies et al. 2011; Miller et al. 2011a). Range expansion has primarily occurred through encroachment into sagebrush communities (Fig. 3a). Early-succession woodlands are now burning in large, highseverity wildfires due to heavy woody-fuel loading and extensive horizontal-to-vertical fuel connectivity (Fig. 3b; Miller and Tausch 2001). Tree infill on late-succession woodlands (Fig. 3c) and extreme fire weather have increased the occurrence of large, high-severity woodland fires in recent decades (Keane et al. 2008). Cheatgrass invasion into pinyon-juniper woodlands (Fig. $3 d$ ) across the western US has amplified the risk of large-scale fires associated with the annual grass-fire cycle (Young and Evans 1978; Tausch 1999; Getz and Baker 2008; Shinneman and Baker 2009). Historical wildfire regimes in pinyon and juniper woodlands consisted of high-severity fires every few hundred or more years (Baker and Shinneman 2004; Romme et al. 2009). Therefore, severity of modern woodland wildfires is within the historical range of variability, but the relatively high frequency of large fires and annual area burnt on woodlands in the past 20 years is likely unprecedented (Keane et al. 2008).

Much of the interior western US now exists in a state in which rangeland and woodland wildfires stimulated by cheatgrass and dense fuels have a greater likelihood of progressing upslope into xeric forests where fire activity is also increasing (Keane et al. 2008; Nelson and Pierce 2010; Balch et al. 2013). Wildfire activity in western xeric forests is dictated by low fuel moisture and cyclonic weather conducive to ignitions and fire spread (Heyerdahl et al. 2002; Gedalof et al. 2005; Heyerdahl et al. 2008a; Morgan et al. 2008; Taylor et al. 2008; Whitlock et al. 2008; Miller et al. 2009). In recent decades, warmer winter and spring air temperature trends at mid-elevations in the western US have resulted in decreased snowpacks (Mote et al. 2005; Regonda et al. 2005; Knowles et al. 2006; Trenberth et al. 2007; Bonfils et al. 2008; Nayak et al. 2010), earlier spring snowmelt and streamflow (McCabe and Clark 2005; Regonda et al. 2005; Stewart et al. 2005; Pederson et al. 2011) and drier fuels (Westerling et al. 2006). These shifts have lengthened fire seasons and increased fire frequency and area burnt in western forests (Pierce et al. 2004; Westerling et al. 2006; Morgan et al. 2008; Pierce and Meyer 2008; Littell et al. 2009).

Climate projections forecast geographic and elevation shifts in fuels that influence fire activity and a persistence of current fire trends along the rangeland-xeric forest continuum (Bradley et al. 2009; Balch et al. 2013). Abatzoglou and Kolden (2011) suggested cheatgrass invasibility and the length of the fire season in the Great Basin will be enhanced by a warmer climate and an increase in wet winters. Wisdom et al. (2003) estimated at least $35 \%$ of Great Basin shrublands remain at high risk of woodland encroachment, potentially pre-conditioning these areas to extreme fire behaviour (Keane et al. 2008). Miller and Tausch (2001) forecasted that land area covered by dense woodlands and the occurrence of high severity woodland fires will increase substantially in the next 40 or more years. Across the interior west, cheatgrass is migrating upslope (Keeley and McGinnis 2007; McGlone et al. 2009; Griffith and Loik 2010; 

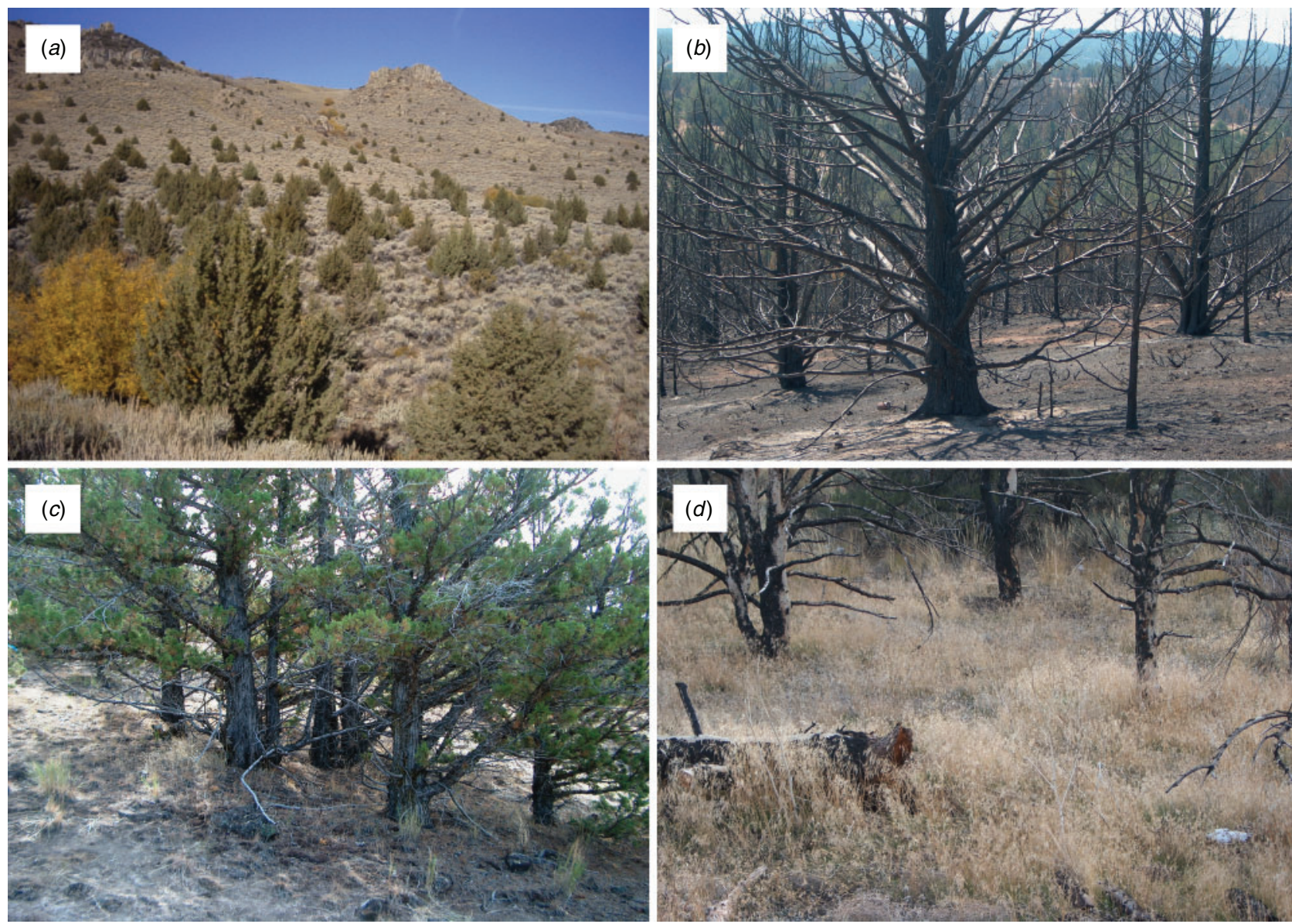

Fig. 3. Woodland encroachment on sagebrush rangeland (a); woodland burnt by high-severity wildfire $(b)$; tree infill into persistent woodland $(c)$ and cheatgrass invasion of a burnt woodland $(d)$

Bromberg et al. 2011), potentially introducing the grass-fire cycle at higher elevations and in xeric forests. Xeric forests adjacent to grass-dominated hillslopes will likely undergo more frequent burning than those distant from grass-dominated hillslopes (Gartner et al. 2012). Projections of climate and plant community transitions are highly variable (Bradley 2009), but most forecast warming, increased dry-season cyclonic storms, longer fire seasons and greater wildfire activity across the rangeland-xeric forest domain of the western US (Price and Rind 1994; Flannigan et al. 2000; Whitlock et al. 2003; Brown et al. 2004; Gedalof et al. 2005; Running 2006; Flannigan et al. 2009; Spracklen et al. 2009; Littell et al. 2010; Abatzoglou and Kolden 2011).

Paleo-erosion records link periods of high wildfire activity in the western US with flooding and increased erosion (Meyer et al. 1995, 2001; Meyer and Pierce 2003; Pierce et al. 2004; Pierce and Meyer 2008; Pierce et al. 2011). In recent decades, extensive damage to natural resources, property, and city infrastructures, and loss of human life have been well documented for post-fire flood events in the western US (Cannon et al. 2001a; Moody and Martin 2001a; Klade 2006; Cannon et al. 2011). Our ability to accurately forecast these effects and the potential hazards for values-at-risk is limited with respect to current wildfire activity (Miller et al. 2011b). Resource managers in the western US are challenged with rapidly evaluating fire effects on ecosystems, determining potential hazards to values-at-risk and conducting cost-benefit analyses of mitigation options (Calkin et al. 2007; Robichaud et al. 2010a). The capability of risk assessments to accurately evaluate hazards and apportion mitigation expenditures requires continued improvement in understanding fire effects, development of predictive technologies, and transfer of information and tools to resource managers (Robichaud et al. 2009; Robichaud and Ashmun 2013).

Current knowledge of fire effects on soils, runoff and erosion is largely based on field studies of sagebrush rangelands (Artemisia spp.; Pierson et al. 2001, 2002, 2008a, 2008b, 2009), semi-arid woodlands (Pierson et al. 2013; Williams et al. 2013), chaparral (see DeBano et al. 1998; Shakesby and Doerr 2006), forests (Robichaud et al. 2000; Benavides-Solorio and MacDonald 2001, 2005; Larsen et al. 2009; Robichaud et al. $2010 a, 2010 b$ ) and Mediterranean scrublands (Cerdà 1998; Cerdà and Doerr 2005, 2008; Shakesby 2011). These studies offer valuable insight into post-fire watershed response and development of hydrologic risk assessment strategies associated with increasing wildfire activity. In this paper, we review current understanding of the hydrologic effects of increasing wildfire activity across the rangeland-xeric forest continuum in the interior western US (Fig. 1) and determine key knowledge 
gaps for addressing the associated hazards to values-at-risk. Our objectives are: (1) summarise current knowledge of wildfire effects on soils, runoff and erosion; (2) frame current knowledge in a conceptual model for increasing the understanding of fireinduced hydrologic risk; and (3) identify the main knowledge gaps that limit improvement of post-fire risk assessment for increased wildfire activity.

\section{Fire effects on soils, runoff and erosion}

\section{Water availability and surface soil conditions}

The first-order effect of fire on runoff and erosion is decreased interception. Unburnt shrubs and conifers can intercept as much as $35 \%$ and $80 \%$ of rainfall during high and low intensity storms, decreasing water available for runoff and erosion (Rowe 1948; Hamilton and Rowe 1949; Skau 1964; Tromble 1983; Owens et al. 2006). Rainfall interception by rangeland plants can reduce erosivity of high-intensity rainfall by $50 \%$, thereby decreasing soil detachment by rain drops (Wainwright et al. 1999; Martinez-Mena et al. 2000). Numerous studies in forested areas have found rainfall erosivity and its dissipation by cover to be primary factors controlling post-fire erosion rates (Inbar et al. 1998; Moody and Martin 2001b; Benavides-Solorio and MacDonald 2005; Spigel and Robichaud 2007; Robichaud et al. 2008; Moody and Martin 2009; Robichaud et al. 2013a, 2013b). Reduction of vegetation by fire may also result in less snow accumulation and subsequent decreases in soil water recharge and vegetation recovery. Spatial and temporal patterns of snow accumulation and melt exert significant control on soil water input, vegetation recruitment and productivity, and hydrologic processes in snow-dominated semi-arid landscapes (Flerchinger et al. 1998; Flerchinger and Cooley 2000; McNamara et al. 2005; Seyfried et al. 2009; Williams et al. 2009; Ebel et al. 2012a). Dense shrub cover $\left(2.2\right.$ plants $\left.\mathrm{m}^{-2}\right)$ can intercept and store $37-61 \%$ of snowfall on rangelands (Hull 1972; Hull and Klomp 1974). Reduced snow accumulation after fire may have minor influence on soil water storage where seasonal snowmelt input is substantial enough to return soils to field capacity (Ebel et al. 2012a).

Hydrologically important soil properties are strongly influenced by organic matter and soil fauna and microorganisms that are altered to varying degrees by burning (Raison 1979; Certini 2005; Shakesby and Doerr 2006; Mataix-Solera et al. 2009, 2011). Soil organic matter is combusted at temperatures above $200^{\circ} \mathrm{C}$ and is completely consumed at $450-500^{\circ} \mathrm{C}$ (DeBano et al. 1998; Neary et al. 1999). These temperatures are well within the range of those commonly reported for rangeland and xeric forest soils during wildfire (Wright and Bailey 1982; Neary et al. 1999). The combustion of organic matter in soils can alter soil structure, increase bulk density and decrease porosity and infiltration capacity (Giovannini et al. 1988; Giovannini and Lucchesi 1997; Hester et al. 1997; Pierson et al. 2001, 2002; Hubbert et al. 2006; Stoof et al. 2010). Aggregate stability promotes infiltration and soil resistance to erosion and may be unaffected, reduced or increased by burning. Moderate- to highseverity burning of soils stabilised by organic matter commonly reduces aggregate stability through combustion of the binding agent (Mataix-Solera et al. 2011). Some studies have found an increase in aggregate stability after fire associated with formation of hydrophobic soils (Mataix-Solera and Doerr 2004; Arcenegui et al. 2008; Jordán et al. 2011). Aggregate stability of soils with high clay content may be enhanced by high-severity burning due to thermal fusion of clay particles into coarser particles (Giovannini et al. 1988; Giovannini and Lucchesi 1997; Mataix-Solera et al. 2011). However, fusion of clay to silt or sand particles can increase soil erosion due to the loss of the cohesive properties inherent to clay soils (Badía and Martí 2003; Hubbert et al. 2006). Burning may also reduce the role of invertebrates, microorganisms, and fungal mycorrhizae in facilitating soil aggregation and infiltration (DeBano et al. 1998; Shakesby and Doerr 2006; Mataix-Solera et al. 2009). Soil temperatures of $40-210^{\circ} \mathrm{C}$ are fatal for most fungi and soil organisms, and organic matter combustion and nutrient volatilisation at soil temperatures above $200^{\circ} \mathrm{C}$ reduce the primary food source for soil fauna production (DeBano et al. 1998; Neary et al. 1999; Certini 2005; Mataix-Solera et al. 2011). Finally, soil moisture retention, a key component of plant and soil fauna productivity, can also be adversely affected by burning due to loss of soil organic matter, pore structure and surface insulation by litter (DeBano et al. 1998; Stoof et al. 2010; Ebel 2012, 2013).

Soil heating may alter or create hydrophobic and/or hyperdry soil conditions (Krammes and DeBano 1965; DeBano and Krammes 1966; Savage 1974; DeBano et al. 1998; Doerr et al. 2000; Hubbert et al. 2006; Pierson et al. 2008b; Doerr et al. 2009a; Moody et al. 2009; Pierson et al. 2009; Moody and Ebel 2012). During fires, organic matter combustion at the soil surface radiates heats downward into the soil profile and vaporises organic substances. Some of these substances are translocated downward along temperature gradients until they condense, forming a variable-thickness hydrophobic patch (DeBano et al. 1970; Savage et al. 1972; Savage 1974; DeBano et al. 1976; DeBano 2000; Doerr et al. 2004). Naturally occurring or 'background' soil water repellency has been commonly observed beneath unburnt conifers and shrubs (Lebron et al. 2007; Madsen et al. 2008; Pierson et al. 2008b; Doerr et al. 2009b; Pierson et al. 2009, 2010, 2013; Williams et al. 2013) and is typically unaffected by soil temperatures $<175^{\circ} \mathrm{C}$. Soil temperatures of $175-270^{\circ} \mathrm{C}$ may enhance 'background' water repellency or create hydrophobic soil conditions (Doerr et al. $2000,2009 a$ ). Water repellency breaks down or is destroyed at soil temperatures of $270-400^{\circ} \mathrm{C}$ (Savage et al. 1972; DeBano et al. 1976; Giovannini and Lucchesi 1997; Doerr et al. 2004). Fire-enhanced or -induced soil water repellency is commonly found within a few centimetres of the soil surface and rapidly decreases in strength with increasing soil depth (Doerr et al. 2009a). Repellency strength and its effect on runoff pre- and post-fire is highly variable in space and time due to inherent variability in pre-fire vegetation, soil properties and conditions, and burn severity (Dekker et al. 2001; Huffman et al. 2001; MacDonald and Huffman 2004; Woods et al. 2007; Pierson et al. 2008b; Woods and Balfour 2008; Pierson et al. 2009, 2010; Stoof et al. 2011; Bodí et al. 2013; Williams et al. 2013). The effects of repellency on runoff generation are even more severe under hyper-dry (extremely dry) conditions immediately following high-severity fire. Extreme heating during high-severity fire can dry out small and large pores within the upper soil profile, potentially causing partial pore structure collapse 
(Moody et al. 2009; Moody and Ebel 2012). Hyper-dry conditions require soils to be rewet before capillary and gravitydriven infiltration can occur (Moody and Ebel 2012).

\section{Runoff and erosion at the small-plot scale}

Small plot $(0.7 \times 0.7 \mathrm{~m})$ rainfall simulation studies by the authors (see Table 1) on steeply sloped (35-60\%) sagebrush hillslopes demonstrate the effects of vegetation cover removal, surface alteration and soil water repellency on post-fire runoff and erosion from rangelands and woodlands. For example, Pierson et al. (2002) investigated the hydrologic effects of wildfire on north- and south-facing sagebrush hillslopes 1 year after the Eighth Street Fire, near Boise, Idaho. Only the southfacing hillslope results are presented here. Runoff and erosion pre-fire were low from shrub coppices (areas beneath shrub canopies) and interspaces (areas between shrub canopies) due to rainfall interception by the canopy and litter and high surface roughness (Table 1). Moderate- and high-severity burning reduced vegetation and litter biomass by $75-99 \%$ and decreased surface roughness by $40 \%$. Approximately $30-50 \%$ of applied rainfall post fire was lost to runoff over the nearly uniformly bare surface (Table 1). Fire had a greater effect on erosion than on runoff (Table 1) and severe burning increased soil erosion 10-fold from coppices and 40-fold from interspaces (Table 1). Higher runoff rates following fire were attributed to decreased interception, persistence of pre-fire soil water repellency, and reduced surface water detention following litter removal and reduced surface roughness. Increased erosion following burning was attributed to greater raindrop detachment and more efficient sediment transport, as well as increased erodibility on interspace microsites.

A 3-year investigation by Pierson et al. (2001, 2008a, 2008b; Table 1) measured infiltration, runoff, and erosion from rainsplash and sheetflow following the Denio Fire, in Nevada. The fire removed nearly all of the canopy and ground cover from well-vegetated, steep sagebrush hillslopes. Runoff increased by $20 \%$ immediately following burning on shrub coppices but decreased on interspaces by $40 \%$ (Table 1 ). The difference between runoff on burnt and unburnt coppices was attributed to the removal of canopy and ground cover by fire on strongly water repellent soils. Decreased runoff from interspace areas was associated with removal of water-shedding senescent vegetation (Pierson et al. 2001) and fire-reduced soil water repellency (Table 1). A decrease in soil water repellency by $50-60 \%$ on all plots 1 year after fire was concurrent with a nearly $40 \%$ increase in infiltration (Fig. 4a). A subsequent $40-50 \%$ increase in soil water repellency on all plots 2 years after fire coincided with a $5-15 \%$ decrease in infiltration (Fig. $4 a$; Pierson et al. $2008 a, 2008 b$ ). Overall, canopy and ground cover removal controlled water availability whereas the strength of soil water repellency exerted greater influence on infiltration and runoff. Interestingly, burning increased erosion from coppices 3-fold but had no effect on interspace erosion (Table 1). The differing responses were attributed to a more erodible surface and greater runoff on coppices after burning. Erosion 1 year after fire was greatly reduced on all plots and similar for burnt and unburnt conditions. Two years after fire, burnt coppice plots generated 3-14 times more erosion than all other plots. Soil water repellency and infiltration were the only other variables showing the same temporal trend, implicating runoff and continued increased erodibility as causal factors (Pierson et al. 2008a).

Pierson et al. (2008b, 2009; Table 1) measured infiltration, runoff and erosion from small-plot rainfall simulations on burnt and unburnt sagebrush hillslopes the year of, and 1 year following, the Breaks Prescribed-Fire in the Reynolds Creek Experimental Watershed, Idaho. The fire reduced canopy cover to $0-10 \%$ (Table 1) and litter cover to 36 and $14 \%$ for shrub coppice and interspace plots. Runoff doubled on coppice plots immediately after fire due to canopy and ground cover reductions, decreased surface roughness and strong post-fire soil water repellency (Table 1). Burning of interspaces reduced runoff (Table 1). One year after fire, a significant decrease (by $70 \%$ ) in soil water repellency on burnt and unburnt coppices and nearly uniform slight soil water repellency across all plots resulted in a 2-fold increase in infiltration (Fig. 4b). As in the Pierson et al. (2008a) study (Table 1), cover influenced water availability, but the strength of soil water repellency exerted a greater influence on infiltration (Fig. $4 b$ ) and runoff of available water. The fire had an even greater effect on erosion than on runoff (Table 1). Reductions in canopy and ground cover increased sediment yield 10-fold on coppices and 3-fold on interspaces. Fire-induced increases in erosion on coppices were attributed to greater runoff and erodibility after fire whereas significantly increased erodibility alone explained the post-fire erosion increase from interspaces (Pierson et al. 2009).

Benavides-Solorio and MacDonald (2001, 2002; Table 1) measured runoff from burnt and unburnt areas of a ponderosa pine forest in the Colorado Front Range, Colorado. Runoff (Table 1) from plots burnt at high severity was well correlated $\left(R^{2}=0.81\right)$ with the strength of soil water repellency. Runoff was not well correlated with percentage slope or bare ground. Benavides-Solorio and MacDonald (2001) concluded that soil water repellency and soil moisture, as a controller of repellency strength, were the primary controls on runoff. Percentage bare soil explained $79 \%$ of erosion on all plots, and soil water repellency explained $43 \%$ of the variability in erosion on plots burnt with high-severity fire (Benavides-Solorio and MacDonald 2001). Erosion on moderate- and high-severity burnt plots was 2 and 16 times greater than those on unburnt or low-severity plots (Table 1).

In a forest study, Woods and Balfour (2008) evaluated the effects of ash on runoff from rainfall simulation plots 1 month following high-severity wildfire. Rainfall was applied to $0.5-\mathrm{m}^{2}$ plots at $75-\mathrm{mm} \mathrm{h}^{-1}$ intensity for $1 \mathrm{~h}$. They found that ash provided $15 \mathrm{~mm}$ of water storage capacity and protected the soil surface from sealing immediate after fire. Time-to-ponding was $12 \mathrm{~min}$ longer and cumulative infiltration was $20 \mathrm{~mm}$ greater on ash- than on ash-free plots. Nine months after the fire, ash-covered and ash-free plots exhibited similar runoff behaviour. Similar ash cover and runoff relationships have been reported in studies by Cerdà and Doerr (2008), Larsen et al. (2009), Woods and Balfour (2010) and Ebel et al. (2012b). Bodí et al. (2011) found that ash may alter soil wettability, inducing surface soil water repellency when ash is hydrophobic and reducing surface soil water repellency when ash is wettable. In a laboratory rainfall simulation study, Bodí et al. (2012) found that a saturated ash layer promoted runoff generation from wettable soils and that an unsaturated ash layer of more than $5-\mathrm{mm}$ depth protected the soil surface from rainsplash erosion 


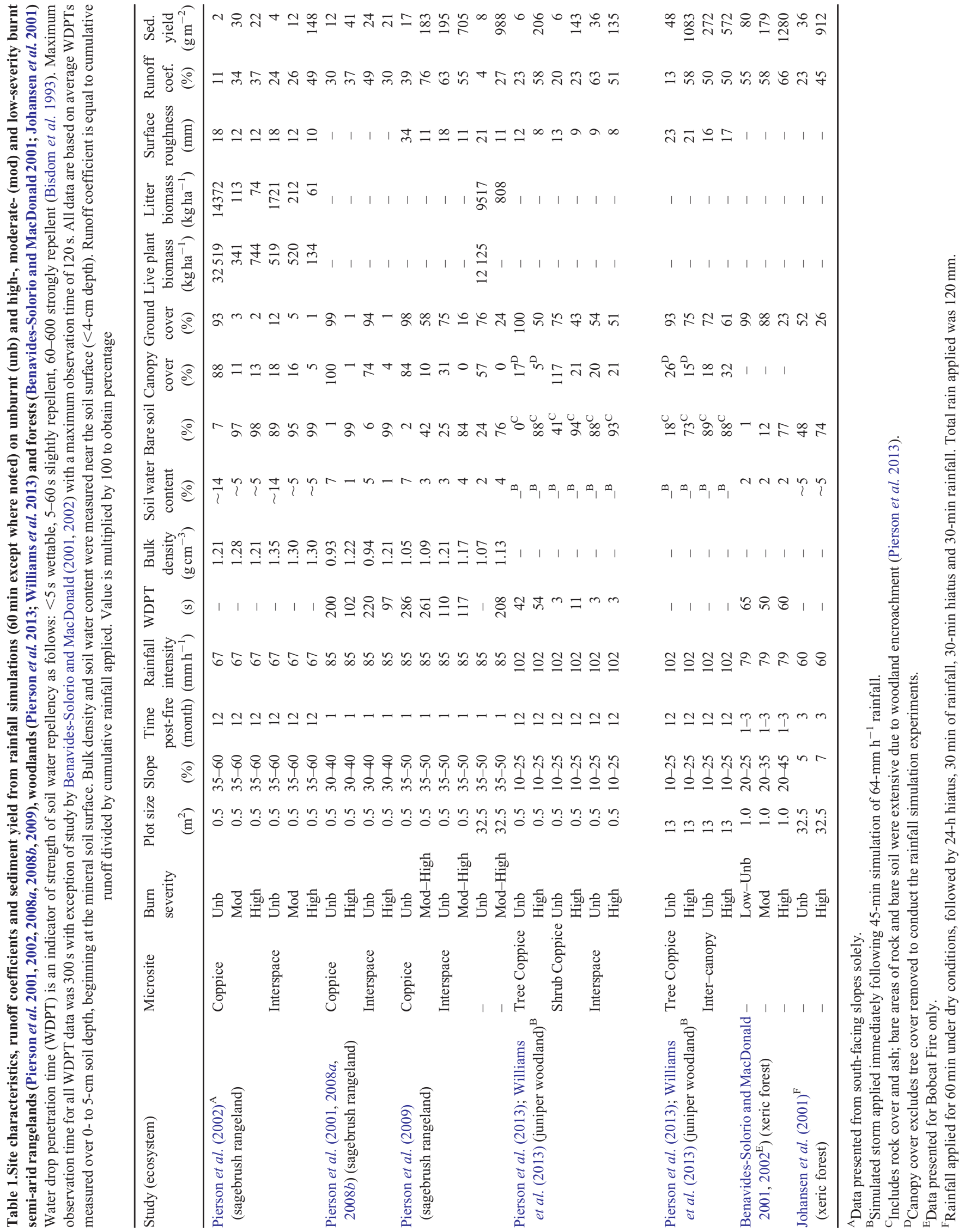



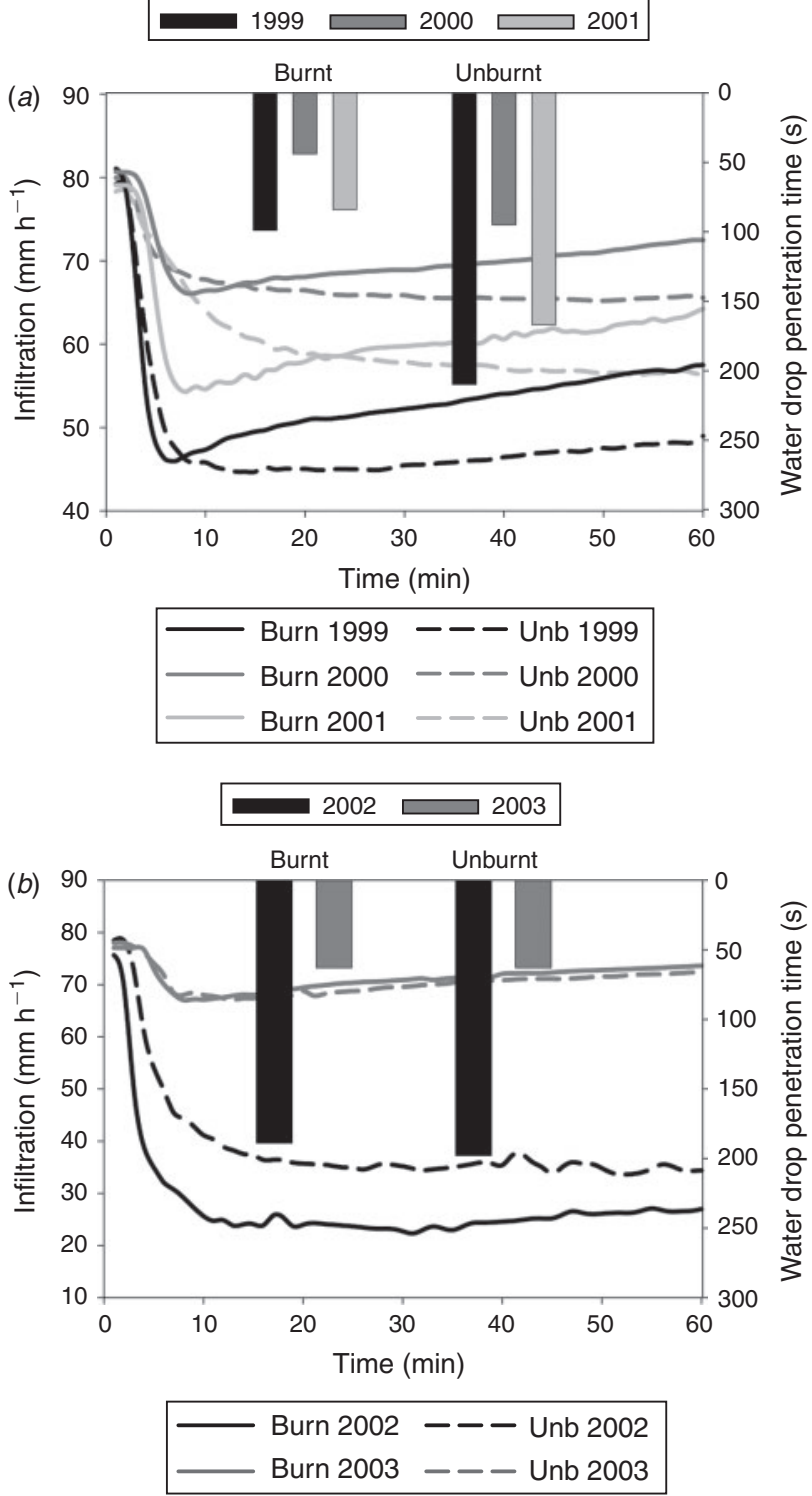

Fig. 4. Infiltration of simulated rainfall $\left(85-\mathrm{mm}-\mathrm{h}^{-1}\right.$ intensity) and strength of soil water repellency (measured as water drop penetration time, WDPT) on sagebrush rangeland in Nevada, USA (a) (Pierson et al. 2008a, 2008b) and Idaho, USA (b) (Pierson et al. 2009).

and improved infiltration into water repellent soils by fingered sub-surface flow. The study also found multiple rain events altered physical and hydraulic properties of the ash layer and reduced its effectiveness to buffer runoff generation and soil erosion. Likewise, Larsen et al. (2009) indicated that the positive effect of ash on infiltration is likely short-lived, and that soil sealing following winnowing of ash particles may promote runoff, especially on water repellent soils (e.g. Onda et al. 2008).

\section{Runoff and erosion processes at large-plot to hillslope scales}

Large-plot scale effects of burning are generally greater for erosion than for runoff due to a change from rainsplash-sheetflow to concentrated flow as the dominant process. Steep slope angles on burnt hillslopes promote concentration of runoff
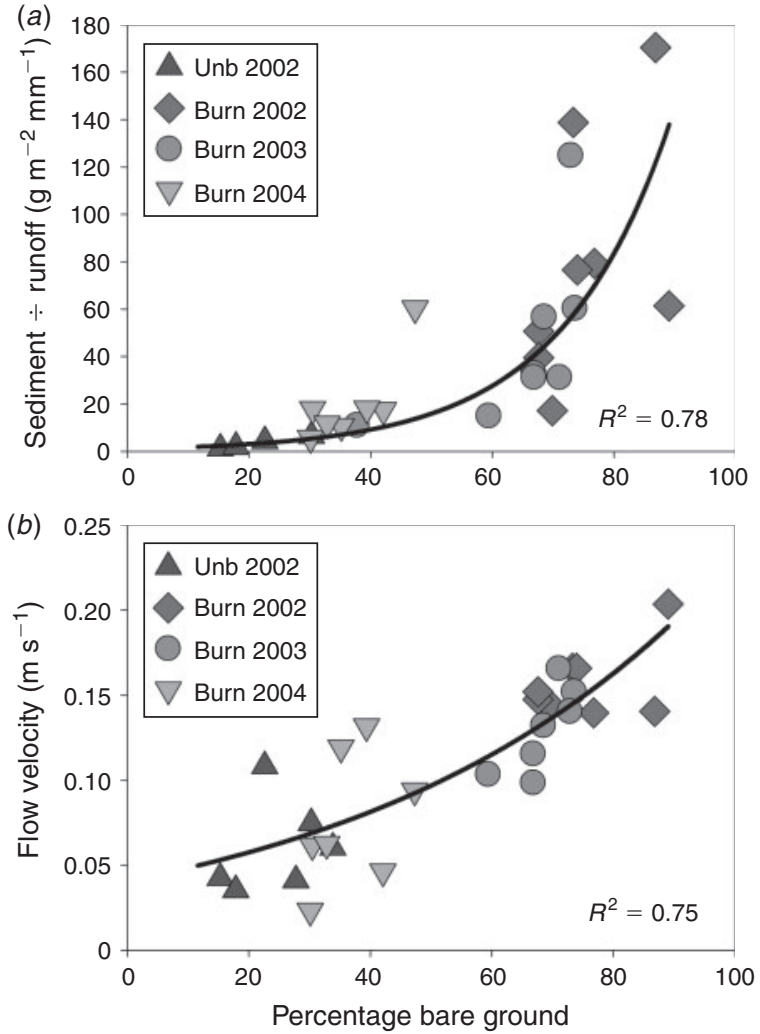

Fig. 5. Sediment yield per unit of runoff $(a)$ and velocity of concentrated flow $(b)$ compared with bare ground measured for rainfall simulation plots $\left(32.5 \mathrm{~m}^{2}, 85 \mathrm{~mm} \mathrm{~h}^{-1}, 60 \mathrm{~min}\right)$ and overland flow experiments $\left(12 \mathrm{~L} \mathrm{~min}^{-1}\right)$ respectively on burnt (Burn) and unburnt (Unb) areas of sagebrush rangeland immediately (2002), and 1 (2003) and 2 (2004) years after fire. Data from Pierson et al. (2009).

(Pietraszek 2006; Spigel and Robichaud 2007; Pierson et al. 2009; Al-Hamdan et al. 2012a, 2013). Concentrated flow has a higher velocity than sheetflow and is therefore capable of eroding and transporting more sediment. Pierson et al. (2009) measured a 7 -fold increase in runoff from $32.5 \mathrm{~m}^{2}$ rainfall simulation plots immediately following burning of steeply sloped sagebrush rangeland (Table 1). Greater runoff under burnt than unburnt conditions was attributed to a 3-fold ground cover reduction, canopy removal, decreased surface roughness, persistent soil water repellency and formation of high-velocity concentrated flowpaths. Runoff returned to pre-fire levels within one growing season due to a 3-fold reduction in strength of soil water repellency and ground cover recovery to $40 \%$. Burning increased erosion more than 120-fold (Table 1, Fig. $5 a$ ) as a result of high velocity concentrated flow and greater runoff after fire. Cumulative runoff from consecutive 12-min releases of 7, 12, 15 and $21 \mathrm{~L} \mathrm{~min}^{-1}$ of concentrated flow was $406 \mathrm{~L}$ on burnt plots immediately following fire and $144 \mathrm{~L}$ on unburnt plots. Mean erosion from concentrated flow experiments was $14363 \mathrm{~g}$ on the burnt plots and $2420 \mathrm{~g}$ on unburnt plots (Pierson et al. 2009). Concentrated flow velocities were 1.5-2.6 times higher on burnt than on unburnt plots the year of the fire and increased exponentially with increasing bare ground (Fig. 5b). Erosion from artificial rainfall and simulated concentrated flow 
on burnt hillslopes approached that of unburnt hillslopes once ground cover recovered to near $60 \%$ ( $40 \%$ bare ground) two growing seasons after fire (Fig. $5 a$ ).

Limited data are available for large-plot-scale runoff and erosion from pinyon-juniper communities. Pierson et al. (2013) and Williams et al. (2013) measured runoff and erosion from $13-\mathrm{m}^{2}$ rainfall simulations in burnt and unburnt areas of a western juniper ( $J$. occidentalis Hook.) site 1 year after fire (Table 1). Runoff from unburnt areas beneath junipers and from the intercanopy area between trees was negligible $(2-6 \mathrm{~mm})$ for a $64 \mathrm{~mm} \mathrm{~h}^{-1}, 45$-min duration storm on dry antecedent moisture conditions. Runoff from the same storm applied to burnt tree and intercanopy plots generated 17 and $4 \mathrm{~mm}$ of runoff. The study applied a higher intensity $\left(102 \mathrm{~mm} \mathrm{~h}^{-1}, 45 \mathrm{~min}\right)$ simulated storm to all plots within $\sim 30 \mathrm{~min}$ of the simulation under dry conditions (Table 1). Runoff was greater for the high intensity storm, but the effects of burning on runoff were significant only for tree plots. Runoff from tree plots was four times higher for burnt than unburnt conditions and was equivalent to that of the intercanopy (Table 1). Approximately $50 \%$ of rainfall applied to burnt and unburnt intercanopy plots was converted to runoff. Erosion was high from unburnt intercanopy plots and increased 2-fold in the intercanopy after fire. Erosion increased more than 20-fold on tree plots after fire (Table 1). Williams et al. (2013) attributed the lack of fire effects on runoff from intercanopy plots to the already high runoff rates. Increased runoff and erosion following burning of tree plots was attributed to fire removal of dense litter cover on water repellent soils and formation of concentrated flow (Pierson et al. 2013; Williams et al. 2013).

The effects of burning and storm intensity on large-plot-scale runoff and erosion from semi-arid forests are well documented (see Robichaud et al. 2000; Cerdà and Robichaud 2009; Moody and Martin 2009). Johansen et al. (2001; Table 1) found that runoff from rainfall simulations on burnt and unburnt areas of a ponderosa pine site was positively correlated $(r=0.76)$ with percentage bare soil, and that time to runoff was negatively correlated $(r=0.67)$ with percentage bare soil. Burning increased runoff and erosion 2- and 25-fold (Table 1). Soil water repellency was highly variable spatially and had minimal effect on runoff. Erosion was strongly correlated with percentage bare soil $(r=0.84)$. Wagenbrenner et al. (2006) found that hillslope soil erosion $\left(1900 \mathrm{~m}^{2}\right.$ plots) from burnt forests of the Colorado Front Range returned to pre-fire levels once ground cover increased to $60 \%$. Benavides-Solorio and MacDonald (2005) used silt fences $\left(190-6600 \mathrm{~m}^{2}\right)$ to measure post-fire erosion from forested slopes $(25-45 \%)$ in the Colorado Front Range over varying fire severities. Over the 2-year study, percentage bare soil explained $\sim 64 \%$ of the variability in soil erosion $(n=48)$. Approximately $90 \%$ of the sediment collected was delivered by high-intensity convective storms. Bare soil and rainfall erosivity together explained $65 \%$ of sediment production variability. Sediment yield decreased exponentially with time after fire and was highest where bare soil approached and exceeded $60 \%$. Soil water repellency was weakly correlated with sediment production from all plots $\left(R^{2} \approx 0.30\right)$, but was more strongly correlated for the high-severity plots $\left(R^{2} \approx 0.40\right)$. Concentrated flow played an important role in post-fire erosion rates on converging topography (Benavides-Solorio and
MacDonald 2005). Spigel and Robichaud (2007) used silt fences ( $\sim 100-\mathrm{m}^{2}$ contributing area) to measure erosion responses from severely burnt, sloping (50-60\% gradient) forest sites in Montana. They concluded that rainfall intensity was the dominant control on erosion from individual storms. More than $2000 \mathrm{~g} \mathrm{~m}^{-2}$ of soil was eroded during short-duration, highintensity storms $\left(75-\mathrm{mm} \mathrm{h}^{-1}\right.$ intensity, at least 10 -min duration) on sites with $60-90 \%$ bare soil and water-repellent soils. Ground cover and soil conditions influenced responses for low-intensity storms, but storms exceeding $\sim 70-\mathrm{mm} \mathrm{h}^{-1}$ intensity over 10 min intervals led to substantial erosion regardless of site conditions. Spigel and Robichaud (2007) observed prominent, dense rill or concentrated flow networks during high intensity storms.

\section{Runoff and erosion at hillslope to watershed scales}

Flooding and extensive soil erosion are common where highintensity storms occur over large areas of recently burnt, sloping terrain along the rangeland-xeric forest continuum (Craddock 1946; Cannon 2001; Cannon et al. 1998, 2001a, 2001b; Meyer et al. 2001; Moody and Martin 2001a; Pierson et al. 2002; Pierce et al. 2004; Klade 2006; Cannon et al. 2008; Pierce et al. 2011). Large erosion events following wildfires are typically triggered by runoff and progressive sediment bulking (Cannon et al. 2001a). For example, a torrential rainstorm 2 months after the South Canyon Fire in Colorado caused nearly 90 runofftriggered debris-flow events that inundated a 13-14-ha area with $\sim 70000 \mathrm{~m}^{3}$ of soil (Cannon et al. 1998, 2001a). The fire occurred on steep $(30-70 \%)$ pinyon-juniper and shrub-dominated hillslopes. Increased runoff and erosion from rainsplash and sheetflow on bare soils facilitated formation of concentrated-flow networks and gullies with high erosive energy and sediment transport capacity. Debris flows developed during the storm mainly through bulking as the flows moved downslope, entrained material and converged in drainage channels with accumulations of wind-blown sediment. Flow velocities were estimated at 3-9 $\mathrm{m} \mathrm{s}^{-1}$ (Cannon et al. 1998). Pierson et al. (2002) documented a runoff-triggered response to a shortduration high-intensity storm on steep sagebrush hillslopes 1 year after the 1996 Eighth Street Fire (6070 ha) along the Boise Front Range, Idaho. A 5-10-year return-interval storm $\left(67 \mathrm{~mm} \mathrm{~h}^{-1}\right)$ lasting $9 \mathrm{~min}$ generated concentrated flow networks, flash flooding and mudflows from bare (90-100\% bare ground), water-repellent soils with reduced water storage capacity and low surface roughness. In an adjacent basin on the Boise Front, similar conditions immediately following multiple cheatgrass-fuelled wildfires in 1959 resulted in widespread flooding and extensive property damage (Klade 2006). Meyer et al. (2001) reported that a short-duration, high-intensity storm on severely burnt ponderosa pine hillslopes in Idaho generated runoff-triggered debris flows. They found incised concentrated flow paths on the steeply sloping terrain integrated into gullies more than $1 \mathrm{~m}$ deep. The gullies promoted highvelocity, erosive discharge that generated sediment-laden flows reaching the North Fork Boise River. Debris flows on burnt hillslopes can also be initiated by debris slides or shallow landslides of large masses of saturated sediment (Meyer et al. 2001; Meyer and Pierce 2003; Wondzell and King 2003; Pierce et al. 2004; Parise and Cannon 2012). Debris slides are most common 4 years or more following burning of forested areas due 
largely to declining root strength of dead trees (Meyer et al. 2001; Meyer and Pierce 2003). The studies described above clearly demonstrate that plot- to hillslope-scale effects potentially influence hydrologic and erosional responses to intense rainfall over contiguous burnt terrain.

\section{Hydrologic risks associated with altered fire regimes}

Clearly, increased wildfire activity along the rangeland-xeric continuum poses significant environmental, social and economic consequences associated with flooding and erosion. More frequent and larger fires increase the likelihood and potential magnitude of onsite and offsite effects. More frequent exposure, as a result of burning surface cover, subjects the soil surface to repeated erosion from frequently occurring storms and increases the probability that the soil surface will be exposed when lessfrequent, high-intensity rainfall events occur. Larger fires create more extensive surface exposure. Annual soil loss from burnt hillslopes in sloping terrain can be $60-100 \mathrm{Mg} \mathrm{ha}^{-1}$ the first year following fire and may take 4-7 years to return to background levels (Mayor et al. 2007; Robichaud 2009). Such losses are detrimental if repeated on 5-10-year rotations. Loss of biologically important surface soils may be particularly critical for rangelands where soil formation takes decades (Allen et al. 2011; Sankey et al. 2012), especially where large fires are followed by drought years with minimal plant recruitment. Soils transported into sideslopes and hollows onsite may serve as a source for downstream sediment pulses during subsequent high-intensity, channel-flushing events (Cannon et al. 2001a; Meyer and Pierce 2003; Pierce et al. 2004; Robichaud et al. 2013b) that negatively affect water resources, fisheries and channel geomorphology (Minshall et al. 2001; Pierce et al. 2011). Studies by Meyer and Pierce (2003), Pierce et al. (2004) and Pierce and Meyer (2008) found that large debris flow events in the interior western US are linked to warm climatic conditions (Medieval Warm Period, 1050-750 years ago) associated with large, stand-replacing fires in xeric forests. The studies further showed that recent warming trends in western xeric forests are concomitant with occurrences of large wildland fires and post-fire debris flows. Large fireinduced debris flows are capable of transporting tremendous volumes of sediment and debris into main stem rivers (Cannon et al. 2001a; Meyer et al. 2001; Pierce et al. 2011).

The recent increase in frequent, large wildfires is particularly concerning for communities in the wildland-urban interface. Flooding in these areas presents hazards to property, infrastructure and human life. In 1945, flooding following intense rainfall over a 1 -year-old $300+$-ha cheatgrass burn caused more than US\$6 million (2013 values) in damage to property in Salt Lake City, Utah (Craddock 1946). Multiple post-fire flooding events in the 1950s and 1990s along the Boise Front Range caused damage to property and infrastructure in the Boise metropolitan area of Idaho exceeding a value of US\$4 million at 2013 rates (Klade 2006). Moody and Martin (2001b) evaluated the hydrologic response to a 100 -year rainfall event on the 4690-ha Buffalo Creek Fire in steep, forested watersheds of the Colorado Front Range near Denver, Colorado. Two months following fire, a high-intensity $\left(90 \mathrm{~mm} \mathrm{~h}^{-1}, 1 \mathrm{~h}\right)$ rainstorm caused flash flooding that killed two people and discharged enough sediment into the Strontia Springs Reservoir to reduce storage capacity by one-third (Agnew et al. 1997; Moody and Martin 2001a).
Cannon et al. (2001a) reported debris flows from a highintensity storm on burnt rangelands in Colorado, which engulfed 30 vehicles travelling on a flow-intersected highway and forced two people into the Colorado River. In Arizona, a 24- $\mathrm{mm} \mathrm{h}^{-1}$, 10 -min storm caused widespread flooding on a recently burnt ponderosa pine site (Neary et al. 2012). The event flooded 85 homes, caused one death and substantially damaged city infrastructure. Post-fire mitigation expenditures exceeded US\$14 million (Coconino County 2011).

Post-fire hillslope hydrologic vulnerability can be conceptualised as a function of storm magnitude (i.e. rainfall intensity) and site susceptibility (Fig. 6). In this model, storm-specific hydrologic vulnerability represents potential runoff and erosion responses for different site susceptibilities. Site susceptibility is defined by the conditions of the soil surface, cover characteristics and topography, and, therefore, encompasses burn severity as well as other key inherent site characteristics (e.g. slope, rock cover, soil erodibility) that influence hydrologic and erosion responses. For a storm of uniform intensity, hydrologic response increases exponentially with increases in site susceptibility due to a shift in hydrologic process dominance from rainsplash and sheetflow to concentrated flow (Fig. 6). Overall hydrologic vulnerability or response increases with increasing storm intensity due to amplified rainfall erosivity and greater water input with higher rainfall intensity. Fire removal of cover and decreased surface roughness increase water available for runoff over pointto small-plot scales and facilitate formation of concentrated flow paths over larger spatial scales. Runoff generation is enhanced where infiltration is inhibited by water-repellent soil conditions and on steep slopes. Fire-induced increases in erodibility and decreased surface protection against rainsplash facilitate soil detachment at small scales and promote sediment delivery by sheetflow and concentrated flow paths over larger spatial scales. Increased erosion with increasing land area results from sediment bulking of the flow as it moves downslope, potentially causing mudslides or debris flows (Cannon et al. 1998, 2001a).

Our qualitative model (Fig. 6) potentially presents a framework with which future quantitative advancements in risk assessment may be made. Kaplan and Garrick (1981) suggested risk, $R$, be defined based on a set of triplets,

$$
R=\left\{<s_{i}, p_{i}, x_{i}>\right\}, i=1,2, \ldots n
$$

where $s_{i}$ refers to the $i$ th scenario or set of conditions, $p_{i}$ is the probability of the $i$ th scenario occurring, and $x_{i}$ is the consequence of the $i$ th scenario. Risk is quantified under this structure by tabulating triplets for all potential scenarios and computing a cumulative probability curve. Site susceptibility and storm intensity (or return interval) in our model of hydrologic vulnerability (Fig. 6) define the $i$ th scenario $\left(s_{i}\right)$, resulting in the $i$ th hydrologic response or consequence $\left(x_{i}\right)$. Vulnerability curves shown for the respective storm intensities in Fig. 6 can be thought of as a family of risk curves (Kaplan and Garrick 1981). The probability of the $i$ th occurrence $\left(p_{i}\right)$ and hydrologic response $\left(x_{i}\right)$ is the combined probability of susceptibility and storm occurrence that define the $i$ th scenario. The potential for damages to values-at-risk is associated with the magnitude of the hydrologic response $\left(x_{i}\right)$, shown by vulnerability curves in Fig. 6, and those damages can be considered as secondary 


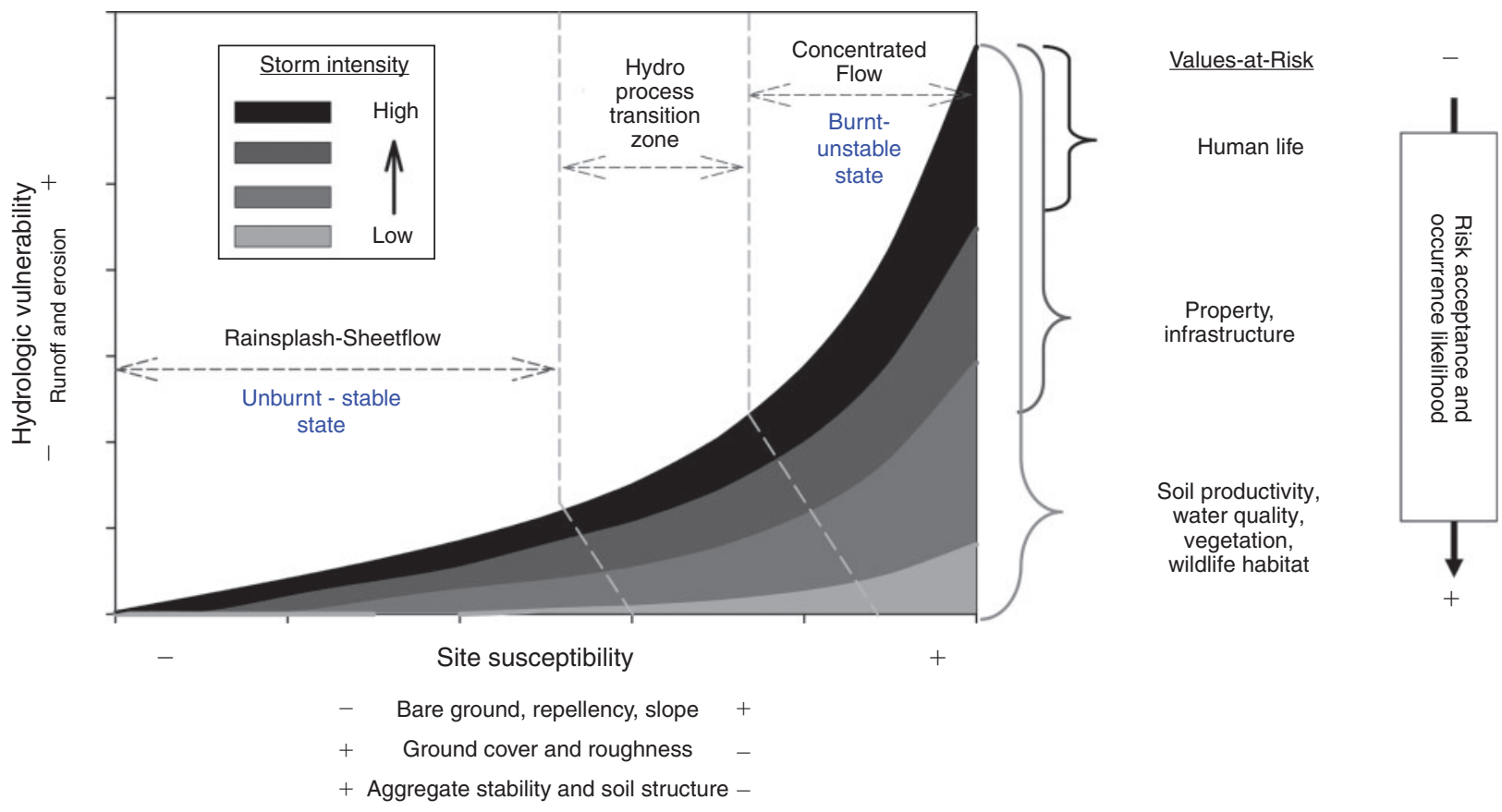

Fig. 6. Conceptual model of hillslope-scale hydrologic vulnerability (runoff and erosion response, $y$-axis) for varying site susceptibility ( $x$-axis) and rainfall intensity. Site susceptibility is defined by the surface soil, ground cover and topographic conditions that affect runoff and erosion responses. Symbols indicate directional increase $(+)$ or decrease $(-)$ in respective variable. Hydrologic vulnerability and response increases exponentially as ground cover, roughness, aggregate stability and soil structure decrease, and bare ground and soil water repellency increase. Responses are amplified with increasing hillslope angle. Rainsplash and sheetflow processes dominate on gentle portions of the vulnerability curves, where conditions are hydrologically stable (unburnt state); concentrated flow dominates where curves steepen and conditions become hydrologically unstable (burnt state). The transition zone occurs where decreased surface protection or increased water availability facilitate concentrated flow initiation. Hydrologic responses are generally greater with increasing rainfall intensity. Potential values-at-risk for varying magnitudes of hydrologic response are shown to illustrate potential consequences of respective runoff and erosion events. Acceptance and likelihood of damage to values-at-risk are illustrated by the arrow on the right side of the figure. Figure is modified from Pierson et al. (2011).

consequences resulting from the $x_{i}$ hydrologic response. Of course, assessing potential harm to values-at-risk requires knowledge of the storm and/or runoff magnitudes necessary to cause the respective damage (for example, see Cannon et al. 2008, 2011). Clearly, such damages occur on western US landscapes (Cannon et al. 1998, 2001a; Meyer et al. 2001; Moody and Martin 2001a; Pierson et al. 2002; Klade 2006; Cannon et al. 2008) and their occurrences will likely be amplified by ongoing increases in wildfire activity. We propose that recent advances in understanding and quantification of fire effects from small-plot to hillslope scales provide an initial point for populating fire effects models in a probabilistic framework that incorporates probabilities of site susceptibility, storm occurrence and magnitude of hydrologic response (e.g. Robichaud et al. 2007; Cannon et al. 2010). The Erosion Risk Management Tool (Robichaud et al. 2007) is one model that, in part, utilises the above conceptual framework to predict hillslope-scale soil erosion in probabilistic terms based on site-specific climate, vegetation, soil texture, burn severity and topography.

\section{Knowledge gaps in the assessment of post-fire hydrologic risk}

This review of post-fire hydrology and erosion studies offers insight into potential confounding issues in the field interpretation of post-fire hydrologic vulnerability. The studies reviewed from burnt rangelands and forested sites (Table 1) demonstrate that field assessments may be challenged by spatial and temporal variability in fire effects and post-fire site conditions, and inherent differences in recovery rates for runoff $v$. erosion. For example, Pierson et al. (2002) found that runoff and erosion on burnt sagebrush rangeland was significantly greater on south-facing than on north-facing slopes 1 year following wildfire. Overland flow generated on south-facing slopes during a convective thunderstorm caused intense flash flooding. Assessment of north-facing slopes alone would not have detected the potential storm response. Runoff and erosional responses may also exhibit temporal variation that masks fire effects. Annual variation in climate influences vegetative recovery, litter recruitment, soil erodibility and soil water repellency. Pierson et al. $(2008 a, 2008 b, 2009)$ reported that temporal variability in naturally occurring (not fire-induced) soil water repellency on burnt sagebrush sites exerted greater influence on runoff than did direct fire effects. Pierson et al. (2009) observed that soil erosion from burnt sagebrush coppices exhibited significant temporal variability, but it was not determined whether this resulted from differences in infiltration, runoff or erodibility. Finally, the conditions required for hydrologic stability differ for runoff $v$. erosion, and for rainsplashsheetflow processes $v$. concentrated flow (Pierson et al. 2008a; 2009). Pierson et al. (2008a, 2009) and Benavides-Solorio 
and MacDonald $(2001,2002)$ have shown that fire effects are greater with respect to erosion than to runoff. Our review of field studies on fire effects indicates that post-fire assessments focusing on one aspect of hydrologic vulnerability (e.g. runoff) or on one process (e.g. rainsplash) may not accurately reflect fire effects. Meaningful field studies of landscape-scale effects may require multiple year assessments, annual control treatments and field evaluation of runoff and erosion at different scales, and should include assessment of rainsplash, sheetflow and concentrated flow processes. However, such comprehensive studies are seldom possible or practical. Investigations that focus on a single hydrologic parameter or process at only one scale should therefore acknowledge the potential errors associated with broad-scale inferences on overall hydrologic vulnerability.

The qualitative model presented in this study (Fig. 6) illustrates the general hydrologic and erosional relationships affected by ongoing plant community transitions and increased fire activity in the western US, but our current ability to populate the model relating to this problem is confounded by several key issues. First, we are still learning how the variables that define site susceptibility at different spatial scales interact to influence hydrologic and erosion responses. Second, current understanding is inadequate with regards to quantifying effects of withinstorm varying rainfall intensity and site conditions. Third, knowledge of how to incorporate soil water repellency and its inherent variability in space and time into predictive models is particularly limiting. Fourth, runoff and erosion data are extremely scant for many plant communities. Finally, advancements in predictive erosion models have been made (e.g. Robichaud et al. 2007; Nearing et al. 2011; Wagenbrenner et al. 2010; Al-Hamdan et al. 2012b), but most models remain focused at the hillslope scale given the lack of watershed-scale data sources. Spatial scaling of hydrologic and erosion processes has long been difficult for scientists, which remains a problem for landscape-scale modelling. Scaling limitations further inhibit linkages of plot- and hillslope-scale responses to offsite effects on values-at-risk (Cawson et al. 2012). Nevertheless, current models based on plot-to-hillslope scale knowledge provide a means of predicting post-fire hillslope responses and evaluating mitigation efforts.

\section{Summary and conclusions}

Increased wildfire activity associated with cheatgrass invasions, plant community transitions and a warming climate along the rangeland-xeric forest continuum in the western US poses hydrologic risks to natural resources, property and human life. Large and frequent fires promote loss of biologically important soils and increase the likelihood of damaging flood and mass erosion events. Projections of climate warming suggest that current trends towards an increase in wildfire activity are likely to continue. Future climate scenarios also predict large-scale shifts in plant communities that may further enhance wildfire activity in the rangeland-xeric forest continuum. Field studies of post-fire runoff and erosion have advanced our understanding of key physical processes and have contributed to hydrologic and erosion model development. In our review, we present a conceptual model of post-fire hydrologic vulnerability and risk based on current understanding, and we identify remaining knowledge gaps that limit post-fire risk assessment. We found that current understanding is lacking in several key areas with regard to quantitative modelling of post-fire hydrologic responses and effects on values-at-risk. Current knowledge is particularly deficient regarding the interacting effects of hydrologic variables (i.e. varying rainfall intensity, infiltration, runoff generation) and spatially variable post-burn conditions and topography. Knowledge of how to incorporate soil water repellency and its variability into hydrologic models is critically limited. Finally, most physically based models are designed to simulate hillslope-scale responses and are not directly applicable to current landscape-scale fires extending across diverse watersheds with steeply sloping xeric forest and rangeland plant communities. Our review suggests that future post-fire risk research should focus on advancing understanding in the key areas noted above and on probability-based modelling of the interacting controls on post-fire responses across relevant spatial scales and for changing climate conditions.

\section{Acknowledgements}

This is Contribution Number 66 of the Sagebrush Steppe Treatment Evaluation Project (SageSTEP), funded by the US Joint Fire Science Program, the Bureau of Land Management and the National Interagency Fire Center. The authors are grateful for the numerous recommendations by the Associate Editor and three anonymous reviewers that improved the clarity and content of the paper. The US Department of Agriculture (USDA) is an equal opportunity provider and employer.

\section{References}

Abatzoglou JT, Kolden CA (2011) Relative importance of weather and climate on wildfire growth in interior Alaska. International Journal of Wildland Fire 20, 479-486. doi:10.1071/WF10046

Agnew W, Labn RE, Harding MV (1997) Buffalo Creek, Colorado, fire and flood of 1996. Land and Water 41, 27-29.

Aguirre L, Johnson DA (1991) Influence of temperature and cheatgrass competition on seedling development of two bunchgrasses. Journal of Range Management 44, 347-354. doi:10.2307/4002397

Al-Hamdan OZ, Pierson FB, Nearing MA, Stone JJ, Williams CJ, Moffet CA, Kormos PR, Boll J, Weltz MA (2012a) Characteristics of concentrated flow hydraulics for rangeland ecosystems: implications for hydrologic modeling. Earth Surface Processes and Landforms 37, 157-168. doi:10.1002/ESP.2227

Al-Hamdan OZ, Pierson FB, Nearing MA, Williams CJ, Stone JJ, Kormos PR, Boll J, Weltz MA (2012b) Concentrated flow erodibility for physically based erosion models: temporal variability in disturbed and undisturbed rangelands. Water Resources Research 48, W07504. doi:10.1029/2011WR011464

Al-Hamdan OZ, Pierson FB, Nearing MA, Williams CJ, Stone JJ, Kormos PR, Boll J, Weltz MA (2013) Risk assessment of erosion from concentrated flow on rangelands using overland flow distribution and shear stress partitioning. Transactions of the ASABE 56, 539-548. doi: $10.13031 / 2013.42684$

Allen EB, Steers RJ, Dickens SJ (2011) Impacts of fire and invasive species on desert soil ecology. Rangeland Ecology and Management 64, 450-462. doi:10.2111/REM-D-09-00159.1

Arcenegui V, Mataix-Solera J, Guerrero C, Zornoza R, Mataix-Beneyto J, García-Orenes F (2008) Immediate effects of wildfires on water repellency and aggregate stability in Mediterranean calcareous soils. Catena 74, 219-226. doi:10.1016/J.CATENA.2007.12.008 
Badía D, Martí C (2003) Plant ash and heat intensity effects on chemical and physical properties of two contrasting soils. Arid Land Research and Management 17, 23-41. doi:10.1080/15324980301595

Baker WL, Shinneman DJ (2004) Fire and restoration of piñon-juniper woodlands in the western United States: a review. Forest Ecology and Management 189, 1-21. doi:10.1016/J.FORECO.2003.09.006

Balch JK, Bradley BA, D’Antonio CM, Gomez-Dans J (2013) Introduced annual grass increases regional fire activity across the arid western USA (1980-2009). Global Change Biology 19, 173-183. doi:10.1111/GCB.12046

Benavides-Solorio J, MacDonald LH (2001) Post-fire runoff and erosion from simulated rainfall on small plots, Colorado Front Range. Hydrological Processes 15, 2931-2952. doi:10.1002/HYP.383

Benavides-Solorio J, MacDonald LH (2002) Erratum. Post-fire runoff and erosion from simulated rainfall on small plots, Colorado Front Range. Hydrological Processes 16, 1131-1133.

Benavides-Solorio JDD, MacDonald LH (2005) Measurement and prediction of post-fire erosion at the hillslope scale, Colorado Front Range. International Journal of Wildland Fire 14, 457-474. doi:10.1071/ WF05042

Bisdom EBA, Dekker LW, Schoute JFT (1993) Water repellency of sieve fractions from sandy soils and relationships with organic material and soil structure. Geoderma 56, 105-118. doi:10.1016/0016-7061(93)90103-R

Bodí MB, Mataix-Solera J, Doerr SH, Cerdà A (2011) The wettability of ash from burned vegetation and its relationship to Mediterranean plant species type, burn severity and total organic carbon content. Geoderma 160, 599-607. doi:10.1016/J.GEODERMA.2010.11.009

Bodí MB, Doerr SH, Cerdà A, Mataix-Solera J (2012) Hydrological effects of a layer of vegetation ash on underlying wettable and water repellent soil. Geoderma 191, 14-23. doi:10.1016/ J.GEODERMA.2012.01.006

Bodí MB, Muñoz-Santa I, Armero C, Doerr SH, Mataix-Solera J, Cerdà A (2013) Spatial and temporal variations of water repellency and probability of its occurrence in calcareous Mediterranean rangeland soils affected by fires. Catena 108, 14-25. doi:10.1016/J.CATENA. 2012.04.002

Bonfils C, Santer BD, Pierce DW, Hidalgo HG, Bala G, Das T, Barnett TP, Cayan DR, Doutriaux C, Wood AW, Mirin A, Nozawa T (2008) Detection and attribution of temperature changes in the mountainous western United States. Journal of Climate 21, 6404-6424. doi:10.1175/ 2008JCLI2397.1

Bradley BA (2009) Regional analysis of the impacts of climate change on cheatgrass invasion shows potential risk and opportunity. Global Change Biology 15, 196-208. doi:10.1111/J.1365-2486.2008.01709.X

Bradley BA, Mustard JF (2005) Identifying land cover variability distinct from land cover change: cheatgrass in the Great Basin. Remote Sensing of Environment 94, 204-213. doi:10.1016/J.RSE.2004.08.016

Bradley BA, Wilcove DS, Oppenheimer M (2009) Climate change increases risk of plant invasion in the eastern United States. Biological Invasions 12, 1-18.

Bromberg JE, Kumar S, Brown CS, Stohlgren TJ (2011) Distributional changes and range predictions of downy brome (Bromus tectorum) in Rocky Mountain National Park. Invasive Plant Science and Manage ment 4, 173-182. doi:10.1614/IPSM-D-10-00022.1

Brooks ML, D'Antonio CM, Richardson DM, Grace JB, Keeley JE, DiTomaso JM, Hobbs RJ, Pellant M, Pyke D (2004) Effects of invasive alien plants on fire regimes. Bioscience 54, 677-688. doi:10.1641/0006 3568(2004)054[0677:EOIAPO]2.0.CO;2

Brown TJ, Hall BL, Westerling AL (2004) The impact of twenty-first century climate change on wildland fire danger in the western United States: an applications perspective. Climatic Change 62, 365-388 doi:10.1023/B:CLIM.0000013680.07783.DE

Calkin DE, Hyde KD, Robichaud PR, Jones JG, Ashmun LE, Loeffler D (2007) Assessing post-fire values-at-risk with a new calculation tool.
USDA Forest Service, Rocky Mountain Research Station, General Technical Report RMRS-GTR-205. (Fort Collins, CO)

Cannon SH (2001) Debris-flow generation from recently burned watersheds. Environmental \& Engineering Geoscience 7, 321-341.

Cannon SH, Powers PS, Savage WZ (1998) Fire-related hyperconcentrated and debris flows on Storm King Mountain, Glenwood Springs, Colorado, USA. Environmental Geology 35, 210-218. doi:10.1007/ S002540050307

Cannon SH, Kirkham RM, Parise M (2001a) Wildfire-related debris-flow initiation processes, Storm King Mountain, Colorado. Geomorphology 39, 171-188. doi:10.1016/S0169-555X(00)00108-2

Cannon SH, Bigio ER, Mine E (2001b) A process for fire-related debris flow initiation, Cerro Grande Fire, New Mexico. Hydrological Processes 15, 3011-3023. doi:10.1002/HYP.388

Cannon SH, Gartner JE, Wilson RC, Bowers JC, Laber JL (2008) Storm rainfall conditions for floods and debris flows from recently burned areas in southwestern Colorado and southern California. Geomorphology 96, 250-269. doi:10.1016/J.GEOMORPH.2007.03.019

Cannon SH, Gartner JE, Rupert MG, Michael JA, Rea AH, Parrett C (2010) Predicting the probability and volume of postwildfire debris flows in the intermountain western United States. Bulletin of the Geological Society of America 122, 127-144. doi:10.1130/B26459.1

Cannon SH, Boldt EM, Laber JL, Kean JW, Staley DM (2011) Rainfall intensity-duration thresholds for postfire debris-flow emergencyresponse planning. Natural Hazards 59, 209-236. doi:10.1007/ S11069-011-9747-2

Cawson JG, Sheridan GJ, Smith HG, Lane PN (2012) Surface runoff and erosion after prescribed burning and the effect of different fire regimes in forests and shrublands: a review. International Journal of Wildland Fire 21, 857-872. doi:10.1071/WF11160

Cerdà A (1998) Changes in overland flow and infiltration after a rangeland fire in a Mediterranean scrubland. Hydrological Processes $\mathbf{1 2}$ 1031-1042. doi:10.1002/(SICI)1099-1085(19980615)12: 7<1031: AID-HYP636>3.0.CO;2-V

Cerdà A, Doerr SH (2005) Influence of vegetation recovery on soil hydrology and erodibility following fire: an 11-year investigation. International Journal of Wildland Fire 14, 423-437. doi:10.1071/WF05044

Cerdà A, Doerr SH (2008) The effect of ash and needle cover on surface runoff and erosion in the immediate post-fire period. Catena $\mathbf{7 4}$ 256-263. doi:10.1016/J.CATENA.2008.03.010

Cerdà A, Robichaud PR (Eds) (2009) 'Fire Effects on Soils and Restoration Strategies.' (Science Publishers: Enfield, NH)

Certini G (2005) Effects of fire on properties of forest soils: a review. Oecologia 143, 1-10. doi:10.1007/S00442-004-1788-8

Coconino County (2011) Coconino County, Arizona, Schultz Fire Flood Facts. Available at http://www.coconino.az.gov/uploadedFiles/ Board_of_Supervisors/SchultzFlood/Flood-Brochure-Final-to-Print3.1.11.pdf [Verified 18 September 2012]

Craddock GW (1946) Salt Lake City flood, 1945. Proceedings of Utah Academy of Sciences, Arts, and Letters 23, 51-61.

Davies KW, Boyd CS, Beck JL, Bates JD, Svejcar TJ, Gregg MA (2011) Saving the sagebrush sea: an ecosystem conservation plan for big sagebrush plant communities. Biological Conservation $\mathbf{1 4 4}$ 2573-2584. doi:10.1016/J.BIOCON.2011.07.016

Davies GM, Bakker JD, Dettweiler-Robinson E, Dunwiddie PW, Hall SA, Downs J, Evans J (2012) Trajectories of change in sagebrush steppe vegetation communities in relation to multiple wildfires. Ecological Applications 22, 1562-1577.

DeBano LF (2000) The role of fire and soil heating on water repellency in wildland environments: a review. Journal of Hydrology 231-232, 195-206. doi:10.1016/S0022-1694(00)00194-3

DeBano LF, Krammes JS (1966) Water repellent soils and their relation to wildfire temperatures. International Bulletin of the Association of Hydrological Scientists 11(2), 14-19. doi:10.1080/02626666609493457 
DeBano LF, Mann LD, Hamilton DA (1970) Translocation of hydrophobic substances into soil by burning organic litter. Proceedings - Soil Science Society of America 34, 130-133. doi:10.2136/SSSAJ1970. 03615995003400010035X

DeBano LF, Savage SM, Hamilton DA (1976) The transfer of heat and hydrophobic substances during burning. Soil Science Society of America Journal 40, 779-782. doi:10.2136/SSSAJ1976. 03615995004000050043X

DeBano LF, Neary DG, Ffolliott PF (1998) 'Fire's Effects on Ecosystems.' (Wiley: New York)

Dekker LW, Doerr SH, Oostindie K, Ziogas AK, Ritsema CJ (2001) Water repellency and critical soil water content in a dune sand. Soil Science Society of America Journal 65, 1667-1674. doi:10.2136/ SSSAJ2001.1667

Doerr SH, Shakesby RA, Walsh RPD (2000) Soil water repellency: its causes, characteristics and hydro-geomorphological significance. EarthScience Reviews 51, 33-65. doi:10.1016/S0012-8252(00)00011-8

Doerr SH, Blake WH, Shakesby RA, Stagnitti F, Vuurens SH, Humphreys GS, Wallbrink P (2004) Heating effects on water repellency in Australian eucalypt forest soils and their value in estimating wildfire soil temperatures. International Journal of Wildland Fire 13, 157-163. doi:10.1071/WF03051

Doerr SH, Shakesby RA, MacDonald LH (2009a) Soil water repellency: a key factor in post-fire erosion? In 'Fire Effects on Soils and Restoration Strategies'. (Eds A Cerdà, PR Robichaud) pp. 197-224. (Science Publishers: Enfield, NH)

Doerr SH, Woods SW, Martin DA, Casimiro M (2009b) 'Natural background' soil water repellency in conifer forests of the north-western USA: its prediction and relationship to wildfire occurrence. Journal of Hydrology 371, 12-21. doi:10.1016/J.JHYDROL.2009.03.011

Duke SE, Caldwell MM (2001) Nitrogen acquisition from different spatial distributions by six Great Basin plant species. Western North American Naturalist 61, 93-102.

Ebel BA (2012) Wildfire impacts on soil-water retention in the Colorado Front Range, United States. Water Resources Research 48, W12515. doi:10.1029/2012WR012362

Ebel BA (2013) Wildfire and aspect effects on hydrologic states after the 2010 Fourmile Canyon Fire. Vadose Zone Journal 12, . doi:10.2136/ VZJ2012.0089

Ebel BA, Hinckley ES, Martin DA (2012a) Soil-water dynamics and unsaturated storage during snowmelt following wildfire. Hydrology and Earth System Sciences 16, 1401-1417. doi:10.5194/HESS16-1401-2012

Ebel BA, Moody JA, Martin DA (2012b) Hydrologic conditions controlling runoff generation immediately after wildfire. Water Resources Research 48, W03529. doi:10.1029/2011WR011470

Flannigan MD, Stocks BJ, Wotton BM (2000) Climate change and forest fires. The Science of the Total Environment 262, 221-229. doi:10.1016/ S0048-9697(00)00524-6

Flannigan MD, Krawchuk MA, De Groot WJ, Wotton BM, Gowman LM (2009) Implications of changing climate for global wildland fire. International Journal of Wildland Fire 18, 483-507. doi:10.1071/WF08187

Flerchinger GN, Cooley KR (2000) A ten-year water balance of a mountainous semi-arid watershed. Journal of Hydrology 237, 86-99. doi:10. 1016/S0022-1694(00)00299-7

Flerchinger GN, Cooley KR, Hanson CL, Seyfried MS (1998) A uniform versus an aggregated water balance of a semi-arid watershed. Hydrological Processes 12, 331-342. doi:10.1002/(SICI)1099-1085(199802) $12: 2<331::$ AID-HYP580>3.0.CO;2-E

Gartner MH, Veblen TT, Sherriff RL, Schoennagel TL (2012) Proximity to grasslands influences fire frequency and sensitivity to climate variability in ponderosa pine forests of the Colorado Front Range. International Journal of Wildland Fire 21, 562-571. doi:10.1071/WF10103
Gedalof Z, Peterson DL, Mantua NJ (2005) Atmospheric, climatic, and ecological controls on extreme wildfire years in the northwestern United States. Ecological Applications 15, 154-174. doi:10.1890/ 03-5116

Getz HL, Baker WL (2008) Initial invasion of cheatgrass (Bromus tectorum) into burned pinon-juniper woodlands in western Colorado. American Midland Naturalist 159, 489-497. doi:10.1674/0003-0031 (2008)159[489:IIOCBT]2.0.CO;2

Giovannini G, Lucchesi S (1997) Modifications induced in soil physicochemical parameters by experimental fires at different intensities. Soil Science 162, 479-486. doi:10.1097/00010694-199707000-00003

Giovannini G, Lucchesi S, Giachetti M (1988) Effect of heating on some physical and chemical parameters related to soil aggregation and erodibility. Soil Science 146, 255-261. doi:10.1097/00010694198810000-00006

Griffith AB, Loik ME (2010) Effects of climate and snow depth on Bromus tectorum population dynamics at high elevation. Oecologia 164, 821-832. doi:10.1007/S00442-010-1749-3

Hamilton EL, Rowe PB (1949) Rainfall interception by chaparral in California. California Department of Natural Resources, Division of Forestry, California Forest and Range Experiment Station. Unnumbered Publication. (Sacramento, CA)

Harris GA (1967) Some competitive relationships between Agropyron spicatum and Bromus tectorum. Ecological Monographs 37, 89-111. doi: $10.2307 / 2937337$

Hester JW, Thurow TL, Taylor CA, Jr (1997) Hydrologic characteristics of vegetation types as affected by prescribed burning. Journal of Range Management 50, 199-204. doi:10.2307/4002381

Heyerdahl EK, Brubaker LB, Agee JK (2002) Annual and decadal climate forcing of historical fire regimes in the interior Pacific Northwest, USA. The Holocene 12, 597-604. doi:10.1191/ 0959683602HL570RP

Heyerdahl EK, McKenzie D, Daniels LD, Hessl AE, Littell JS, Mantua NJ (2008a) Climate drivers of regionally synchronous fires in the Inland Northwest (1651-1900). International Journal of Wildland Fire 17, 40-49. doi:10.1071/WF07024

Heyerdahl EK, Morgan P, Riser Ii JP (2008b) Multi-season climate synchronized historical fires in dry forests (1650-1900), Northern Rockies, USA. Ecology 89, 705-716. doi:10.1890/06-2047.1

Hubbert KR, Preisler HK, Wohlgemuth PM, Graham RC, Narog MG (2006) Prescribed burning effects on soil physical properties and soil water repellency in a steep chaparral watershed, southern California, USA. Geoderma 130, 284-298. doi:10.1016/ J.GEODERMA.2005.02.001

Huffman EL, MacDonald LH, Stednick JD (2001) Strength and persistence of fire-induced soil hydrophobicity under ponderosa and lodgepole pine, Colorado Front Range. Hydrological Processes 15, 2877-2892. doi:10.1002/HYP.379

Hull AC (1972) Rainfall and snowfall interception of big sagebrush. Proceedings of the Utah Academy of Sciences, Arts, and Letters 49, 64.

Hull AC, Klomp GJ (1974) Yield of crested wheatgrass under four densities of big sagebrush in southern Idaho. USDA Agricultural Research Service, Technical Bulletin 1483. (Washington DC)

Humphrey LD, Schupp EW (2001) Seed banks of Bromus tectorumdominated communities in the Great Basin. Western North American Naturalist 61, 85-92.

Inbar M, Tamir M, Wittenberg L (1998) Runoff and erosion processes after a forest fire in Mount Carmel, a Mediterranean area. Geomorphology 24, 17-33. doi:10.1016/S0169-555X(97)00098-6

Johansen MP, Hakonson TE, Breshears DD (2001) Post-fire runoff and erosion from rainfall simulation: contrasting forests with shrublands and grasslands. Hydrological Processes 15, 2953-2965. doi:10.1002/ HYP. 384 
Jordán A, Zavala LM, Mataix-Solera J, Nava AL, Alanís N (2011) Effect of fire severity on water repellency and aggregate stability on Mexican volcanic soils. Catena 84, 136-147. doi:10.1016/J.CATENA.2010.10.007

Kaplan S, Garrick BJ (1981) On the quantitative definition of risk. Risk Analysis 1, 11-27. doi:10.1111/J.1539-6924.1981.TB01350.X

Keane RE, Agee JK, Fulé P, Keeley JE, Key C, Kitchen SG, Miller R, Schulte LA (2008) Ecological effects of large fires on US landscapes: benefit or catastrophe? International Journal of Wildland Fire 17, 696-712. doi:10.1071/WF07148

Keeley JE, McGinnis TW (2007) Impact of prescribed fire and other factors on cheatgrass persistence in a Sierra Nevada ponderosa pine forest. International Journal of Wildland Fire 16, 96-106. doi:10.1071/ WF06052

Klade RJ (2006) Building a research legacy - the Intermountain Station 1911-1997. USDA Forest Service, Rocky Mountain Research Station, General Technical Report RMRS-GTR-184. (Fort Collins, CO)

Knapp PA (1996) Cheatgrass (Bromus tectorum L) dominance in the Great Basin Desert. History, persistence, and influences to human activities Global Environmental Change 6, 37-52. doi:10.1016/0959-3780(95) 00112-3

Knowles N, Dettinger MD, Cayan DR (2006) Trends in snowfall versus rainfall in the western United States. Journal of Climate 19, 4545-4559. doi:10.1175/JCLI3850.1

Krammes JS, DeBano LF (1965) Soil wettability: a neglected factor in watershed management. Water Resources Research 1, 283-286. doi:10.1029/WR001I002P00283

Larsen IJ, MacDonald LH, Brown E, Rough D, Welsh MJ, Pietraszek JH, Libohova Z, De Dios Benavides-Solorio J, Schaffrath K (2009) Causes of post-fire runoff and erosion: water repellency, cover, or soil sealing? Soil Science Society of America Journal 73, 1393-1407. doi:10.2136/ SSSAJ2007.0432

Lebron I, Madsen MD, Chandler DG, Robinson DA, Wendroth O, Belnap J (2007) Ecohydrological controls on soil moisture and hydraulic conductivity within a pinyon-juniper woodland. Water Resources Research 43, W08422. doi:10.1029/2006WR005398

Link SO, Keeler CW, Hill RW, Hagen E (2006) Bromus tectorum cover mapping and fire risk. International Journal of Wildland Fire $\mathbf{1 5}$ 113-119. doi:10.1071/WF05001

Litschert SE, Brown TC, Theobald DM (2012) Historic and future extent of wildfires in the Southern Rockies Ecoregion, USA. Forest Ecology and Management 269, 124-133. doi:10.1016/J.FORECO.2011.12.024

Littell JS, McKenzie D, Peterson DL, Westerling AL (2009) Climate and wildfire area burned in western US ecoprovinces, 1916-2003. Ecological Applications 19, 1003-1021. doi:10.1890/07-1183.1

Littell JS, Oneil EE, McKenzie D, Hicke JA, Lutz JA, Norheim RA, Elsner MM (2010) Forest ecosystems, disturbance, and climatic change in Washington State, USA. Climatic Change 102, 129-158. doi:10.1007/ S10584-010-9858-X

MacDonald LH, Huffman EL (2004) Post-fire soil water repellency: persistence and soil moisture thresholds. Soil Science Society of America Journal 68, 1729-1734. doi:10.2136/SSSAJ2004.1729

Mack RN (1981) Invasion of Bromus tectorum L. into Western North America: an ecological chronicle. Agro-ecosystems 7, 145-165. doi:10.1016/0304-3746(81)90027-5

Mack RN, Pyke DA (1983) The demography of Bromus tectorum: variation in time and space. Journal of Ecology 71, 69-93. doi:10.2307/2259964

Madsen MD, Chandler DG, Belnap J (2008) Spatial gradients in ecohydrologic properties within a pinyon-juniper ecosystem. Ecohydrology 1 , 349-360. doi:10.1002/ECO.29

Marlon JR, Bartlein PJ, Gavin DG, Long CJ, Anderson RS, Briles CE Brown KJ, Colombaroli D, Hallett DJ, Power MJ, Scharf EA, Walsh MK (2012) Long-term perspective on wildfires in the western USA. Proceedings of the National Academy of Sciences of the United States of America 109, E535-E543. doi:10.1073/PNAS.1112839109
Martinez-Mena M, Alvarez Rogel J, Albaladejo J, Castillo VM (2000) Influence of vegetal cover on sediment particle size distribution in natural rainfall conditions in a semiarid environment. Catena 38 , 175-190. doi:10.1016/S0341-8162(99)00073-9

Mataix-Solera J, Doerr SH (2004) Hydrophobicity and aggregate stability in calcareous topsoils from fire-affected pine forests in southeastern Spain Geoderma 118, 77-88. doi:10.1016/S0016-7061(03)00185-X

Mataix-Solera J, Guerrero C, Garcia-Orenes F, Barcenas GM, Torres MP (2009) Forest fire effects on soil microbiology. In 'Fire Effects on Soils and Restoration Strategies’. (Eds A Cerdà, PR Robichaud) pp. 133-176. (Science Publishers: Enfield, NH)

Mataix-Solera J, Cerdà A, Arcenegui V, Jordán A, Zavala LM (2011) Fire affects on soil aggregation: a review. Earth-Science Reviews 109, 44-60. doi:10.1016/J.EARSCIREV.2011.08.002

Mayor AG, Bautista S, Llovet J, Bellot J (2007) Post-fire hydrological and erosional responses of a Mediterranean landscape: seven years of catchment-scale dynamics. Catena 71, 68-75. doi:10.1016/J.CATENA. 2006.10.006

McCabe GJ, Clark MP (2005) Trends and variability in snowmelt runoff in the western United States. Journal of Hydrometeorology 6, 476-482. doi:10.1175/JHM428.1

McGlone CM, Springer JD, Covington WW (2009) Cheatgrass encroachment on a ponderosa pine forest ecological restoration project in northern Arizona. Ecological Research 27, 37-46 doi:10.3368/ER.27.1.37

McNamara JP, Chandler D, Seyfried M, Achet S (2005) Soil moisture states, lateral flow, and streamflow generation in a semi-arid, snowmeltdriven catchment. Hydrological Processes 19, 4023-4038. doi:10.1002 HYP.5869

Melgoza G, Nowak RS (1991) Competition between cheatgrass and two native species after fire: implications from observations and measurements of root distribution. Journal of Range Management 44, 27-33. doi: $10.2307 / 4002633$

Meyer GA, Pierce JL (2003) Climatic controls on fire-induced sediment pulses in Yellowstone National Park and central Idaho: a long-term perspective. Forest Ecology and Management 178, 89-104. doi:10.1016/S0378-1127(03)00055-0

Meyer GA, Wells SG, Jull AJT (1995) Fire and alluvial chronology in Yellowstone National Park: climatic and intrinsic controls on Holocene geomorphic processes. Geological Society of America Bulletin 107, 1211-1230. doi:10.1130/0016-7606(1995)107<1211: FAACIY $>2.3 . \mathrm{CO} ; 2$

Meyer GA, Pierce JL, Wood SH, Jull AJT (2001) Fire, storms, and erosional events in the Idaho batholith. Hydrological Processes 15, 3025-3038. doi:10.1002/HYP.389

Miller RF, Tausch RJ (2001) The role of fire in juniper and pinyon woodlands: a descriptive analysis. In 'Proceedings of the Invasive Plan Workshop: the Role of Fire in the Control and Spread of Invasive Species, The First National Congress on Fire Ecology, Prevention, and Management', 27 November-1 December 2000, San Diego, CA. (Eds KEM Galley, TP Wilson) Tall Timbers Research Station, Miscellaneous Publication Number 11, pp. 15-30. (Tallahassee, FL)

Miller JD, Safford HD, Crimmins M, Thode AE (2009) Quantitative evidence for increasing forest fire severity in the Sierra Nevada and southern Cascade Mountains, California and Nevada, USA. Ecosystems 12, 16-32. doi:10.1007/S10021-008-9201-9

Miller RF, Knick ST, Pyke DA, Meinke CW, Hanser SE, Wisdom MJ, Hild AL (2011a) Characteristics of sagebrush habitats and limitations to longterm conservation. In 'Greater Sage-Grouse: Ecology and Conservation of a Landscape Species and its Habitats, Studies in Avian Biology (Volume 38)'. (Eds ST Knick, JW Connelly) pp. 145-184. (University of California Press: Berkeley, CA)

Miller ME, MacDonald LH, Robichaud PR, Elliot WJ (2011b) Predicting post-fire hillslope erosion in forest lands of the western United States. 
International Journal of Wildland Fire 20, 982-999. doi:10.1071/ WF09142

Minshall GW, Robinson CT, Lawrence DE, Andrews DA, Brock JT (2001) Benthic macroinvertebrate assemblages in five central Idaho (USA) streams over a 10-year period following disturbance by wildfire. International Journal of Wildland Fire 10, 201-213. doi:10.1071/ WF01018

Moody JA, Ebel BA (2012) Hyper-dry conditions provide new insights into the cause of extreme floods after wildfire. Catena 93, 58-63. doi:10.1016/J.CATENA.2012.01.006

Moody JA, Martin DA (2001a) Initial hydrologic and geomorphic response following a wildfire in the Colorado Front Range. Earth Surface Processes and Landforms 26, 1049-1070. doi:10.1002/ESP.253

Moody JA, Martin DA (2001b) Post-fire, rainfall intensity-peak discharge relations for three mountainous watersheds in the western USA. Hydrological Processes 15, 2981-2993. doi:10.1002/HYP.386

Moody JA, Martin DA (2009) Synthesis of sediment yields after wildland fire in different rainfall regimes in the western United States. International Journal of Wildland Fire 18, 96-115. doi:10.1071/WF07162

Moody JA, Kinner DA, Ubeda X (2009) Linking hydraulic properties of fire-affected soils to infiltration and water repellency. Journal of Hydrology 379, 291-303. doi:10.1016/J.JHYDROL.2009.10.015

Morgan P, Heyerdahl EK, Gibson CE (2008) Multi-season climate synchronized forest fires throughout the 20th century, Northern Rockies, USA. Ecology 89, 717-728. doi:10.1890/06-2049.1

Mote PW, Hamlet AF, Clark MP, Lettenmaier DP (2005) Declining mountain snowpack in western North America. Bulletin of the American Meteorological Society 86, 39-49. doi:10.1175/BAMS-86-1-39

Nayak A, Marks D, Chandler DG, Seyfried M (2010) Long-term snow, climate, and streamflow trends at the Reynolds Creek Experimental Watershed, Owyhee Mountains, Idaho, United States. Water Resources Research 46, W06519. doi:10.1029/2008WR007525

Nearing MA, Wei H, Stone JJ, Pierson FB, Spaeth KE, Weltz MA, Flanagan DC, Hernandez M (2011) A rangeland hydrology and erosion model. Transactions of the ASABE 54, 901-908. doi:10.13031/ 2013.37115

Neary DG, Klopatek CC, DeBano LF, Ffolliott PF (1999) Fire effects on belowground sustainability: a review and synthesis. Forest Ecology and Management 122, 51-71. doi:10.1016/S0378-1127(99)00032-8

Neary DG, Koestner KA, Youberg A, Koestner PE (2012) Post-fire rill and gully formation, Schultz Fire 2010, Arizona, USA. Geoderma 191, 97-104. doi:10.1016/J.GEODERMA.2012.01.016

Nelson NA, Pierce J (2010) Late-Holocene relationships among fire, climate and vegetation in a forest-sagebrush ecotone of southwestern Idaho, USA. The Holocene 20, 1179-1194. doi:10.1177/0959683610371992

NIFC (2012) Wildland fire statistics, National Interagency Fire Center. (Boise, ID) Available at http://www.nifc.gov/fireInfo/fireInfo_statistics. html [Verified 15 September 2012]

Onda Y, Dietrich WE, Booker F (2008) Evolution of overland flow after severe forest fire, Point Reyes, California. Catena 72, 13-20. doi:10.1016/J.CATENA.2007.02.003

Owens MK, Lyons RK, Alejandro CL (2006) Rainfall partitioning within semiarid juniper communities: effects of event size and canopy cover. Hydrological Processes 20, 3179-3189. doi:10.1002/HYP.6326

Parise M, Cannon CH (2012) Wildfire impacts on the processes that generate debris flows in burned watersheds. Natural Hazards 61, 217-227. doi:10.1007/S11069-011-9769-9

Pederson GT, Gray ST, Ault T, Marsh W, Fagre DB, Bunn AG, Woodhouse CA, Graumlich LJ (2011) Climatic controls on the snowmelt hydrology of the northern Rocky Mountains. Journal of Climate 24, 1666-1687. doi:10.1175/2010JCLI3729.

Pierce J, Meyer G (2008) Long-term fire history from alluvial fan sediments: the role of drought and climate variability, and implications for management of Rocky Mountain forests. International Journal of Wildland Fire 17, 84-95. doi:10.1071/WF07027

Pierce JL, Meyer GA, Jull AJT (2004) Fire-induced erosion and millennialscale climate change in northern ponderosa pine forests. Nature $\mathbf{4 3 2}$, 87-90. doi:10.1038/NATURE03058

Pierce JL, Meyer GA, Rittenour T (2011) The relation of Holocene fluvial terraces to changes in climate and sediment supply, South Fork Payette River, Idaho. Quaternary Science Reviews 30, 628-645. doi:10.1016/ J.QUASCIREV.2010.11.013

Pierson FB, Robichaud PR, Spaeth KE (2001) Spatial and temporal effects of wildfire on the hydrology of a steep rangeland watershed. Hydrological Processes 15, 2905-2916. doi:10.1002/HYP.381

Pierson FB, Carlson DH, Spaeth KE (2002) Impacts of wildfire on soil hydrological properties of steep sagebrush-steppe rangeland. International Journal of Wildland Fire 11, 145-151. doi:10.1071/WF02037

Pierson FB, Robichaud PR, Moffet CA, Spaeth KE, Hardegree SP, Clark PE, Williams CJ (2008a) Fire effects on rangeland hydrology and erosion in a steep sagebrush-dominated landscape. Hydrological Processes 22, 2916-2929. doi:10.1002/HYP.6904

Pierson FB, Robichaud PR, Moffet CA, Spaeth KE, Williams CJ, Hardegree SP, Clark PE (2008b) Soil water repellency and infiltration in coarse-textured soils of burned and unburned sagebrush ecosystems. Catena 74, 98-108. doi:10.1016/J.CATENA.2008.03.011

Pierson FB, Moffet CA, Williams CJ, Hardegree SP, Clark PE (2009) Prescribed-fire effects on rill and inter-rill runoff and erosion in a mountainous sagebrush landscape. Earth Surface Processes and Landforms 34, 193-203. doi:10.1002/ESP.1703

Pierson FB, Williams CJ, Kormos PR, Hardegree SP, Clark PE, Rau BM (2010) Hydrologic vulnerability of sagebrush steppe following pinyon and juniper encroachment. Rangeland Ecology and Management 63, 614-629. doi:10.2111/REM-D-09-00148.1

Pierson FB, Williams CJ, Hardegree SP, Weltz MA, Stone JJ, Clark PE (2011) Fire, plant invasions, and erosion events on western Rangelands. Rangeland Ecology and Management 64, 439-449. doi:10.2111/ REM-D-09-00147.1

Pierson FB, Williams CJ, Hardegree SP, Clark PE, Kormos PR, Al-Hamdan OZ (2013) Hydrologic and erosion responses of sagebrush steppe following juniper encroachment, wildfire, and tree-cutting. Rangeland Ecology and Management. doi:10.2111/REM-D-1200104.1

Pietraszek JH (2006) Controls on post-fire erosion at the hillslope scale, Colorado Front Range. MSc thesis, Colorado State University, Fort Collins.

Price C, Rind D (1994) The impact of a $2 \times \mathrm{CO}_{2}$ climate on lightningcaused fires. Journal of Climate 7, 1484-1494. doi:10.1175/1520-0442 (1994)007<1484:TIOACC $>2.0 . C O ; 2$

Prism Climate Group (2012) PRISM Climate Group, Oregon State University. Available at http://prismmap.nacse.org/nn/ [Verified 1 September 2012]

Raison RJ (1979) Modification of the soil environment by vegetation fires, with particular reference to nitrogen transformations: a review. Plant and Soil 51, 73-108, doi:10.1007/BF02205929

Regonda SK, Rajagopalan B, Clark M, Pitlick J (2005) Seasonal cycle shifts in hydroclimatology over the western United States. Journal of Climate 18, 372-384. doi:10.1175/JCLI-3272.1

Robichaud PR (2009) Post-fire stabilization and rehabilitation. In 'Fire Effects on Soils and Restoration Strategies'. (Eds A Cerdà, PR Robichaud) pp. 299-320. (Science Publishers: Enfield, NH)

Robichaud PR, Ashmun LE (2013) Tools to aid post-wildfire assessment and erosion-mitigation treatment decisions. International Journal of Wildland Fire 22, 95-105. doi:10.1071/WF11162

Robichaud PR, Beyers JL, Neary DG (2000) Evaluating the effectiveness of postfire rehabilitation treatments. USDA Forest Service, Rocky 
Mountain Research Station, General Technical Report RMRS-GTR-63. (Fort Collins, CO)

Robichaud PR, Elliot WJ, Pierson FB, Hall DE, Moffet CA (2007) Predicting postfire erosion and mitigation effectiveness with a webbased probabilistic erosion model. Catena 71, 229-241. doi:10.1016/ J.CATENA.2007.03.003

Robichaud PR, Pierson FB, Brown RE, Wagenbrenner JW (2008) Measuring effectiveness of three post-fire hillslope erosion barrier treatments, western Montana, USA. Hydrological Processes 22, 159-170. doi:10.1002/HYP.6558

Robichaud PR, Lewis SA, Brown RE, Ashmun LE (2009) Emergency post-fire rehabilitation treatment effects on burned area ecology and long-term restoration. Fire Ecology 5, 115-128. doi:10.4996/ FIREECOLOGY.0501115

Robichaud PR, Ashmun LE, Sims BD (2010a) Post-fire treatment effectiveness for hillslope stabilization. USDA Forest Service, Rocky Mountain Research Station, General Technical Report RMRSGTR-240. (Fort Collins, CO)

Robichaud PR, Wagenbrenner JW, Brown RE (2010b) Rill erosion in natural and disturbed forests: 1. Measurements. Water Resources Research 46, W10506. doi:10.1029/2009WR008314

Robichaud PR, Lewis SA, Wagenbrenner JW, Ashmun LE, Brown RE (2013a) Post-fire mulching for runoff and erosion mitigation. Part I Effectiveness at reducing hillslope erosion rates. Catena 105, 75-92. doi:10.1016/J.CATENA.2012.11.015

Robichaud PR, Wagenbrenner JW, Lewis SA, Ashmun LE, Brown RE, Wohlgemuth PM (2013b) Post-fire mulching for runoff and erosion mitigation. Part II. Effectiveness in reducing runoff and sediment yields from small catchments. Catena 105, 93-111. doi:10.1016/J.CATENA. 2012.11.016

Romme WH, Allen CD, Bailey JD, Baker WL, Bestelmeyer BT, Brown PM, Eisenhart KS, Floyd ML, Huffman DW, Jacobs BF, Miller RF, Muldavin EH, Swetnam TW, Tausch RJ, Weisberg PJ (2009) Historical and modern disturbance regimes, stand structures, and landscape dynamics in piñon-juniper vegetation of the western United States. Rangeland Ecology and Management 62, 203-222. doi:10.2111/08-188R1.1

Rowe PB (1948) Influence of woodland chaparral on water and soil in central California. California Department of Natural Resources, Division of Forestry, unnumbered publication. (Sacramento, CA)

Running SW (2006) Is global warming causing more, larger wildfires? Science 313, 927-928. doi:10.1126/SCIENCE.1130370

Sankey JB, Germino MJ, Sankey TT, Hoover AN (2012) Fire effects on the spatial patterning of soil properties in sagebrush steppe, USA: a metaanalysis. International Journal of Wildland Fire 21, 545-556. doi:10.1071/WF11092

Savage SM (1974) Mechanism of fire-induced water repellency in soils Proceedings - Soil Science Society of America 38, 652-657. doi:10.2136/SSSAJ1974.03615995003800040033X

Savage SM, Osborn J, Letey J, Heaton C (1972) Substances contributing to fire-induced water repellency in soils. Soil Science Society of America Journal 36, 674-678. doi:10.2136/SSSAJ1972. $03615995003600040047 \mathrm{X}$

Seyfried MS, Grant LE, Marks D, Winstral A, McNamara J (2009) Simulated soil water storage effects on streamflow generation in a mountainous snowmelt environment, Idaho, USA. Hydrological Processes 23, 858-873. doi:10.1002/HYP.7211

Shakesby RA (2011) Post-wildfire soil erosion in the Mediterranean: review and future research directions. Earth-Science Reviews 105, 71-100. doi:10.1016/J.EARSCIREV.2011.01.001

Shakesby RA, Doerr SH (2006) Wildfire as a hydrological and geomorphological agent. Earth-Science Reviews 74, 269-307. doi:10.1016/ J.EARSCIREV.2005.10.006
Shinneman DJ, Baker WL (2009) Environmental and climatic variables as potential drivers of post-fire cover of cheatgrass (Bromus tectorum) in seeded and unseeded semiarid ecosystems. International Journal of Wildland Fire 18, 191-202. doi:10.1071/WF07043

Skau CM (1964) Interception, throughfall, and stemflow in Utah and alligator juniper cover types in northern Arizona. Forest Science 10, 283-287.

Spigel KM, Robichaud PR (2007) First-year post-fire erosion rates in Bitterroot National Forest, Montana. Hydrological Processes 21, 998-1005. doi:10.1002/HYP.6295

Spracklen DV, Mickley LJ, Logan JA, Hudman RC, Yevich R, Flannigan MD, Westerling AL (2009) Impacts of climate change from 2000 to 2050 on wildfire activity and carbonaceous aerosol concentrations in the western United States. Journal of Geophysical Research, D, Atmospheres 114, D20301. doi:10.1029/ 2008JD010966

Stewart IT, Cayan DR, Dettinger MD (2005) Changes toward earlier streamflow timing across western North America. Journal of Climate 18, 1136-1155. doi:10.1175/JCLI3321.1

Stoof CR, Wesseling JG, Ritsema CJ (2010) Effects of fire and ash on soil water retention. Geoderma 159, 276-285. doi:10.1016/J.GEODERMA. 2010.08.002

Stoof CR, Moore D, Ritsema CJ, Dekker LW (2011) Natural and fireinduced soil water repellency in a Portuguese shrubland. Soil Science Society of America Journal 75, 2283-2295. doi:10.2136/SSSAJ2011. 0046

Tausch RJ (1999) Historic pinyon and juniper woodland development In 'Proceedings: ecology and management of pinyon-juniper communities within the Interior West', 15-18 September 1997, Provo, UT (Eds SB Monsen, R Stevens) USDA Forest Service, Rocky Mountain Research Station, RMRS-P-9. pp. 12-19.

Taylor AH, Trouet V, Skinner CN (2008) Climatic influences on fire regimes in montane forests of the southern Cascades, California, USA. International Journal of Wildland Fire 17, 60-71. doi:10.1071/WF07033

Trenberth KE, Smith L, Qian T, Dai A, Fasullo J (2007) Estimates of the global water budget and its annual cycle using observational and model data. Journal of Hydrometeorology 8, 758-769. doi:10.1175 JHM600.1

Tromble JM (1983) Interception of rainfall by tarbush. Journal of Range Management 36, 525-526. doi:10.2307/3897960

USGS (2012) US Land Cover Institute, US Department of Interior, Geologic Survey. Available at http://landcover.usgs.gov/landcoverdata.php [Verified 1 September 2012]

Wagenbrenner JW, MacDonald LH, Rough D (2006) Effectiveness of three post-fire rehabilitation treatments in the Colorado Front Range. Hydrological Processes 20, 2989-3006. doi:10.1002/HYP.6146

Wagenbrenner JW, Robichaud PR, Elliot WJ (2010) Rill erosion in natural and disturbed forests: 2. Modeling approaches. Water Resources Research 46, W10507. doi:10.1029/2009WR008315

Wainwright J, Parsons AJ, Abrahams AD (1999) Rainfall energy under creosotebush. Journal of Arid Environments 43, 111-120. doi:10.1006/ JARE.1999.0540

Welch BL (2005) Big sagebrush: a sea fragmented into lakes, ponds, and puddles. USDA Forest Service, Rocky Mountain Research Station, General Technical Report RMRS-GTR-144. (Fort Collins, CO)

Westerling AL, Hidalgo HG, Cayan DR, Swetnam TW (2006) Warming and earlier spring increase western US forest wildfire activity. Science 313, 940-943. doi:10.1126/SCIENCE.1128834

Whitlock C, Shafer SL, Marlon J (2003) The role of climate and vegetation change in shaping past and future fire regimes in the northwestern US and the implications for ecosystem management. Forest Ecology and Management 178, 5-21. doi:10.1016/S0378-1127 (03)00051-3 
Whitlock C, Marlon J, Briles C, Brunelle A, Long C, Bartlein P (2008) Long-term relations among fire, fuel, and climate in the north-western US based on lake-sediment studies. International Journal of Wildland Fire 17, 72-83. doi:10.1071/WF07025

Whitlock C, Briles CE, Fernandez MC, Gage J (2011) Holocene vegetation, fire and climate history of the Sawtooth Range, central Idaho, USA. Quaternary Research 75, 114-124. doi:10.1016/ J.YQRES.2010.08.013

Williams CJ, McNamara JP, Chandler DG (2009) Controls on the temporal and spatial variability of soil moisture in a mountainous landscape: the signature of snow and complex terrain. Hydrology and Earth System Sciences 13, 1325-1336. doi:10.5194/HESS-131325-2009

Williams CJ, Pierson FB, Al-Hamdan OZ, Kormos PR, Hardegree SP, Clark PE (2013) Can wildfire serve as an ecohydrologic thresholdreversal mechanism on juniper-encroached shrublands? Ecohydrology. [Published online early 24 January 2013] doi:10.1002/ECO.1364

Wisdom MJ, Suring LH, Rowland MM, Schueck L, Tausch RJ, Miller RF, Wolff-Meinke C, Knick ST, Wales BC 2003. A prototype regional assessment of habitats for species of conservation concern in the
Great Basin Ecoregion and state of Nevada, Version 1.1. USDA Forest Service, Pacific Northwest Research Station. (LaGrande, OR)

Wondzell SM, King JG (2003) Postfire erosional processes in the Pacific Northwest and Rocky Mountain regions. Forest Ecology and Management 178, 75-87. doi:10.1016/S0378-1127(03)00054-9

Woods SW, Balfour VN (2008) The effect of ash on runoff and erosion after a severe forest wildfire, Montana, USA. International Journal of Wildland Fire 17, 535-548. doi:10.1071/WF07040

Woods SW, Balfour VN (2010) The effects of soil texture and ash thickness on the post-fire hydrological response from ash-covered soils. Journal of Hydrology 393, 274-286. doi:10.1016/J.JHYDROL. 2010.08.025

Woods SW, Birkas A, Ahl R (2007) Spatial variability of soil hydrophobicity after wildfires in Montana and Colorado. Geomorphology 86, 465-479. doi:10.1016/J.GEOMORPH.2006.09.015

Wright HA, Bailey AW (1982) 'Fire ecology United States and Canada.' (Wiley: New York).

Young JA, Evans RA (1978) Population dynamics after wildfires in sagebrush grasslands. Journal of Range Management 31, 283-289. doi: $10.2307 / 3897603$ 